Eskişehir Osmangazi Üniversitesi iỉBF Dergisi

Nisan 2017, C. 12, S. 1, 99-120

Başvuru :03.10.2016

Kabul : 20.01.2017

\title{
Türkiye İçin Finansal Koşulların Bir Analizi: Faktör ve VAR Modellerinden Bulgular ${ }^{1}$ \\ Coşkun Akdeniz ${ }^{2}$ \\ Abdurrahman Nazif Çatık ${ }^{3}$
}

Türkiye İçin Finansal Koşulların Bir Analizi: Faktör ve VAR Modellerinden Bulgular

Öz

Bu çalışma 1992:1 ve 2015:12 dönemini kapsayacak şekilde Türkiye için alternatif finansal koşullar endekslerinin (FKE) hesaplanması ve öngörü güçlerinin değerlendirilmesini amaçlamaktadır. Bu çerçevede, ilk olarak finansal koşullar endeksleri dört metodolojiye dayanılarak elde edilmiştir: İndirgenmiş form talep denklemleri, VAR genelleştirilmiş etki-tepki fonksiyonları, dinamik faktör modeli ve faktör-genişletilmiş VAR modelleri (FAVARs). Çalışmanın ikinci kısmında alternatif FKE'ler sanayi üretim açığını örneklem içi ve örneklem dışı öngörü gücü açısından karşılaştırılmıştır. Sonuçlar eş varyanslı FAVAR yönteminden elde edilen FKE'nin en iyi örneklem dışı öngörüyü sağladığını ortaya koymaktadır, bu nedenle söz konusu FKE iktisadi aktivitenin öncül bir göstergesi olarak önerilmektedir.

Anahtar Kelimeler: Finansal Koşullar Endeksi, VAR, Dinamik Faktör Modeli, FAVAR.
An Analysis of Financial Conditions for Turkey: Evidences from Factor and VAR models

Abstract

This paper aims to calculate alternative financial conditions indexes ( $\mathrm{FCls}$ ) and evaluate the forecasting performance of them for Turkey covering the period 1992:1 and 2015:12. For this purpose, first financial conditions indexes are constructed based on four methodologies: Reduced form demand functions, VAR generalized impulse-response functions, dynamic factor model and factor-augmented VAR models (FAVARs). In the second part of the study the performance of the alternative $\mathrm{FCls}$ are assessed in terms their in-sample and out-of-sample forecasting ability to industrial production gap. The results suggest that the $\mathrm{FCl}$ obtained from the homoscedastic FAVAR model provides the best out-of-sample forecasts, hence it is suggested as a leading indicator of economic activity.

Keywords: Financial Conditions Index, VAR, Dynamic Factor Model, FAVAR.

\section{Giriş}

Son dönemlerde para politikası uygulamalarında yaşanan gelişmelere paralel olarak merkez bankalarının görev tanımları ve politika araçlarının kapsamı, ekonomilerin içsel koşullarının yanı sıra küresel ekonomik gelişmelerden ötürü zaman içerisinde önemli bir değişim göstermiştir. 1990'lı yıllarda merkez bankalarının nihai amacı fiyat istikrarının sağlanmasıyla sınırlıydı. Bu amaç doğrultusunda enflasyon hedeflemesi rejimi uygulayan merkez bankaları, kısa vadeli faiz oranlarını temel politika aracı olarak kullanmaktaydı. Finansal serbestleşme neticesinde sermayenin tam hareketli hale gelmesiyle, enflasyon hedeflemesi uygulayan ülkeler için kısa vadeli faiz oranlarının yanı sıra reel döviz kuru da önemli bir iktisadi gösterge haline gelmiştir. Bu kapsamda enflasyon hedeflemesi rejimi için kısa vadeli faiz oranları ve reel döviz kurundaki değişimi bir arada yansıtan bir endeksin elde edilmesi ihtiyacı doğmuştur. 1990 yılında Yeni Zelanda ve Kanada Merkez Bankası tarafından hesaplanan söz konusu endeks, parasal koşullar endeksi

\footnotetext{
${ }^{1}$ Bu çalışma Ege Üniversitesi Sosyal Bilimler Enstitüsü İktisat Anabilim Dalı’nda Doç. Dr. Abdurrahman Nazif Çatık danışmanlığında Coşkun Akdeniz tarafından hazırlanan "Türkiye'de Finansal İstikrarın Para Politikası Üzerine Etkisi" başlıklı doktora tezinden türetilmiştir. Yazarlar söz konusu çalışmaya SOBAG 215 K414 nolu proje kapsamında finansal desteklerini sunan TÜBiTAK'a teşekkürlerini sunar.

${ }^{2}$ Arş. Gör., Ege Üniversitesi iiBF, i̇ktisat Bölümü. coskun.akdeniz@ege.edu.tr

${ }^{3}$ Doç. Dr., Ege Üniversitesi IïBF, İktisat Bölümü. a.nazif.catik@ege.edu.tr
} 
(monetary conditions index, PKE) olarak adlandırılmıştır. Kısa vadeli faiz ve reel döviz kuru değişkenlerinin ağılıklı ortalamasından elde edilen PKE, halen operasyonel hedef ve gösterge endeks olarak Yeni Zelanda, Kanada, Avrupa ve ABD merkez bankaları tarafından kullanılmaktadır.

PKE içerdiği değişkenlerin kısıtlılı̆ı, parasal aktarım mekanizmasını sadece faiz oranı ve döviz kuru kanalları üzerinden açıklayabilmesi ve finansal koşulları tam olarak yansıtamaması nedeniyle eleştirilmiştir. PKE'ye getirilen eleştiriler, finansal piyasalarda yaşanan değişimler ve merkez bankalarının görev tanımlarının genişlemesi; para politikası yapıcılarını parasal ve finansal koşullardaki değişmeyi birlikte yansıtan daha kapsamlı politika göstergelerinin geliştirilmesine yöneltmiştir. Bu bağlamda PKE kısa ve uzun dönemli faiz oranları, döviz kuru, risk primi, kredi hacmi, parasal büyüklükler, beklenti anketleri, hisse senedi ve konut fiyatları gibi makro ve finansal değişkenleri içerecek şekilde genişletilerek yeni bir endeks oluşturulmuştur. illk kez Goodhart ve Hofmann (2001) tarafından hesaplanan endeks, finansal koşullar endeksi (financial conditions index, FKE) olarak adlandırılmaktadır. FKE'nin PKE'ye göre en önemli avantajı; sadece politika faiz oranı ve döviz kuru yerine içerdiği küresel finansal değişkenler ile dış koşullardaki değişmelerin, ulusal ekonomi üzerindeki etkilerini de hesaba katarak ölçmesidir.

Parasal ve finansal koşulları bir arada yansıtan FKE, çok sayıda ekonomik ve finansal değişkenin bileşiminden oluşmaktadır. Para politikası uygulayıcıları açısından FKE'nin tercih edilmesine ilişkin çeşitli nedenler sıralanabilir. Illk olarak endeks iktisadi aktivitenin öncü bir göstergesi olarak, ekonominin gelecekteki durumu hakkında bilgi verme potansiyeline sahiptir. íkinci olarak FKE'nin hesaplanmasında kullanılan endeks ağırlıkları, endekste yer alan değişkenlerin iktisadi aktivite ve finansal koşullara olan etkilerinin miktarsal olarak belirlenmesine imkan sağlamaktadır. Son olarak FKE finansal koşullardaki genişleme ve daralma dönemlerini ortaya koyarak, finans piyasalarındaki değişmelerin önceden tespit edilmesine yardımcı olmaktadır (Kara vd., 2015). Söz konusu piyasalardaki gelişmelerin önceden doğru bir şekilde tahmin edilebilmesi, uygulanması planlanan para politikalarının etkinliğinin artmasında da önemli bir rol oynayabilir.

Bu çalışmanın temel amacı Türkiye için finansal koşullardaki değişmenin en iyi şekilde belirlenmesini sağlayabilecek bir FKE'nin hesaplanmasıdır. Bu çerçevede Türkiye'nin incelendiği önceki çalışmalardan farklı olarak söz konusu endeksin hesaplanmasında; literatürde son dönemde geliştirilen genelleştirilmiş dinamik faktör ve FAVAR modelleri kullanılacaktır. Ayrıca elde edilen endeksler, iktisadi aktiviteyi öngörü gücü açısından karşılaştırılarak en iyi endeks belirlenecektir.

Çalışma altı kısımdan oluşmaktadır. İzleyen bölümde FKE'lerin hesaplandığı çalışmalara ilişkin bir literatür taraması sunulacaktır. Çalışmada kullanılan veri setine ilişkin bilgiler üçüncü bölümde verilmektedir. FKE'lerin hesaplanmasında kullanılan modellerin yapısına metodoloji kısmında değinilecektir. Ampirik sonuçlar kısmında FKE'ler hesaplanarak, iktisadi aktiviteyi öngörü güçleri açısından karşılaştırılacaktır. Çalışmanın sonuç kısmında ise elde edilen ampirik sonuçlar çerçevesinde, Türkiye'de finansal koşullardaki değişmelerin belirleyicilerine ilişkin politika çıkarsamalarında bulunulacaktır.

\section{Literatür Taraması}

FKE üzerine yapılan çalışmalar incelendiğinde iki önemli sonuç ortaya çıkmaktadır. Birincisi endekslerin önemli bir kısmının ABD ekonomisi için hesaplandığı, gelişmekte olan piyasalar için ise sınırlı sayıda çalışmanın yapıldığı görülmektedir. Söz konusu endeksler özellikle 2008 küresel finans krizi sonrasında merkez bankaları tarafından yaygın olarak kullanılmaya başlanarak; Citibank, Deutsche Bank, Macroeconomic Adviser, Bloomberg, Goldman Sachs, Ekonomik 
Kalkınma ve İşbirliği Örgütü (OECD) ile IMF gibi uluslararası finans kuruluşları tarafından da hesaplanmaktadır (Hatzius vd., 2010). İkinci önemli sonuç ise endeks bileşenlerinde yer alan değişkenlerin kapsamı ve kullanılan yöntemler açısından, literatürün ilk örnekleri ile son dönem çalışmalar arasında önemli farklılıkların bulunmasıdır. Bu açıdan endeks hesaplamalarına ilişkin ilk çalışmalarda, daha kısıtlı değişken seti üzerinden doğrusal yöntemlerin kullanıldığı göze çarpmaktadır. Ayrıca hesaplanan endekslerin büyük bir kısmında hedef değişken olarak üretim düzeyi kullanılarak, elde edilen endekslerin hedef değişkeni öngörü performansı değerlendirilmiştir.

Goodhart ve Hofmann'ın (2001) G7 ülkelerini ele aldıkları çalışmalarında, indirgenmiş form toplam talep modeli ve VAR etki-tepki fonksiyonları kullanılmıştır. Kısa dönem reel faiz oranı, reel efektif döviz kuru, reel konut fiyatları ve reel hisse senedi fiyatlarının endeks bileşenleri olarak kullanıldığı çalışma sonuçlarına göre; analiz kapsamındaki ülkelerin hemen hepsinde indirgenmiş form modelinden elde edilen endekslerde, varlık fiyatlarının üretim açığını anlamlı bir şekilde etkilediği tespit edilmiştir. VAR etki-tepki sonuçlarında ise faiz oranları ve konut fiyatlarına verilen şokların üretim açığı ve enflasyonu anlamlı bir şekilde etkilediği, ancak döviz kuruna verilen şokların ise analize dahil edilen ülkelerin sadece yarısında anlamlı etkilere sahip olduğu gözlemlenmiştir.

Gauthier vd. (2004) Kanada Merkez Bankası için hesapladıkları endekste indirgenmiş form talep denklemleri, VAR etki-tepki fonksiyonları ve faktör analizi yöntemlerini kullanmışlardır. Elde edilen endeksler ağırlıkların ekonomik teoriyle tutarlıı̆̆ı, grafiksel olarak konjonktür dalgalanmalarındaki dönüm noktalarını tespit kabiliyeti, üretim ile dinamik korelasyonu, örneklem içi ve örneklem dışı üretimi tahmin performansına göre değerlendirilmiştir. Çalışma sonucunda konut fiyatları, varlık fiyatları ve döviz kurunun üretimin anlamlı açıklayıcı değişkenleri olduğu tespit edilmiştir.

Montagnoli ve Napolitano (2006) ABD, Kanada, Euro Bölgesi ve Birleşik Krallık için söz konusu endekslerin hesaplanmasında Kalman filtresi yöntemini kullanmışlardır. Bu yaklaşım finansal değişkenlerin ağılıklarının, zaman içerisinde değişmesine olanak sağlaması açısından çok önemlidir. Kısa dönem faiz oranları, reel efektif döviz kuru, tüketici fiyat endeksi, konut fiyatları, sanayi üretimi ve hisse senedi endekslerinin kullanıldığı çalışmadan elde edilen sonuçlara göre; FKE'lerin kısa dönem faiz oranlarının tespit edilmesinde ABD, Kanada ve Birleşik Kralıı merkez bankaları için anlamlı ve pozitif işaretli olduğu bulunmuştur.

Swiston (2008) çalışmasında kredi koşullarının ABD için konjonktür dalgalanmalarındaki rolünü tespit etmiş̧ir. VAR etki-tepki fonksiyonlarının kullanıldığı çalışmada; kredi standartlarının reel sektöre olan nihai etkisinin, esasen diğer finansal değişkenlerin anlamlı tepkileri üzerinden ortaya çıktığı vurgulanmaktadır. Elde edilen endeksin reel gayri safi yurt içi hasıla (GSYiH) artışının doğru tahmincisi olduğu ve altı aydan dokuz aya kadarki ekonomik aktivitelerin dönüm noktalarını öngörebildiği ifade edilmiştir.

Hatzius vd. (2010) ABD için finansal koşullar ve ekonomik faaliyet arasındaki ilişkiyi incelemişlerdir. Çalışma sonuçlarına göre kredi koşulları ve akımlarda daralma meydana gelmesi durumunda, fiyat sinyallerinin daha az güvenilir hale geldiği ortaya konmaktadır. Hesaplanan endeksler üzerinden 2010'a kadar finansal koşullarda süregelen daralmanın, iktisadi aktiviteye olan etkisi net bir şekilde tespit edilmiştir. Endeksin özellikle finansal stres dönemlerinde iyi çalıştığını belirten yazarlar, endeksin makroekonomik etkilerden arındııılmasıyla performansının arttığı sonucuna ulaşmışlardır. 
ABD ekonomisini ele alan bir diğer çalışmada ise Koop ve Korobilis $(2013,2014)$, makroekonomik etkilerden arındırılmış şekilde tanımladıkları endeksin hesaplanmasında FAVAR modellerini kullanmışlardır. Çalışmada 1959-2012 dönemi için çeyreklik sıklıkta veriler üzerinden, Kalman filtresi aracılığıyla hesaplanan çeşitli FAVAR modelleri tahmin edilmiştir. Zamanla değişen parametreli FAVAR (TVP-FAVAR), FAVAR (FA-TVP-VAR), eş varyanslı FAVAR (HM-FAVAR) ve değişen varyanslı FAVAR (HT-FAVAR) modelleri kullanılarak hesaplanan endekslerin, ABD ekonomisi için hesaplanan önceki FKE'ler ile benzer sonuçlar verdiği saptanmıştır. Ancak önemli finansal stres (1970'ler sonu, $1980^{\prime}$ ler başı ve son finansal kriz) dönemlerinde, mevcut endekslere nazaran daha istikrarlı sonuçlar verdiği tespit edilmiştir. Öngörü performansı açısından TVP-FAVAR modelinin, doğrusal VAR ve FAVAR modellerine göre daha iyi bir performans gösterdiği sonucuna ulaşılmıştır.

Osorio, Pongsaparn ve Ünsal (2011) çalışmalarında Avusturya, Çin, Hong Kong, Hindistan, Endonezya, Japonya, Kore, Malezya, Yeni Zelanda, Filipinler, Singapur, Tayland ve Çin Tayvan Eyaleti'ni ele almışlardır. VAR genelleştirilmiş etki-tepki fonksiyonları ve temel bileşenler yöntemlerinin kullanıldığı çalışmada, FKE'lerin GSYiH'yı öngörü güçleri değerlendirilmiştir. Elde edilen endekslere göre; küresel kriz öncesinde finansal koşullarda meydana gelen daralma, hisse senedi piyasalarındaki kayıplar ve kredi koşullarının daralması nedeniyle ortaya çıkmaktadır. 2010'un ilk aylarında ise uyumlu para politikaları ve varlık fiyatlarındaki toparlanma nedeniyle finansal koşulların kriz öncesi seviyelere ulaştığı tespit edilmiştir.

Gumata, Klein ve Ndou (2012) Güney Afrika ekonomisi için 1999:1-2011:4 dönemini kapsayan çeyreklik veriler ile temel bileşenler analizi ve Kalman filtresi yaklaşımlarını kullanmışlardır. Tahmin edilen alternatif endekslerin zaman içerisinde benzer bir eğilim gösterdiğini belirten yazarlar, kısa dönem GSYiH değişimi için endeksin güçlü bir öngörü bilgisine sahip olduğunu tespit etmişlerdir. Güney Afrika ekonomisi için yapılan çalışmalardan bir diğeri de Thompson vd.'nin (2013) hesapladıkları endekstir. Küresel ve yerel finansal göstergeleri kapsayan endeks, 1966:02-2012:01 dönemi için elde edilmiştir. Çalışmada özyineli (recursive) ve özyineli olmayan (non-recursive) yöntemlerle temel bileşenler yaklaşımı kullanılmıştır. Hesaplanan endeksin sanayi üretimi, enflasyon ve hazine bonosunun iyi bir tahmincisi olduğu tespit edilmiştir.

Angelopoulou, Balfoussia ve Gibson (2014) çalışmalarında Euro bölgesi ve parasal birlik içeresindeki Almanya, Yunanistan, Portekiz, İspanya ülkeleri için FKE'ler hesaplamışlardır. Aylık serilerin kullanıldığı çalışma 2003-2011 dönemini kapsamaktadır. Sadece para politikası değişkenlerinden elde edilen endeksin, özellikle küresel kriz döneminde finansal koşullardaki daralmayı ölçmede başarısız olduğu tespit edilmiştir. Bir başka değişle para politikası değişkenlerinin, finansal koşullardaki değişimlerin küçük bir kısmını açıklayabildiği vurgulanmıştır.

Yapılan literatür taramasında Türkiye ekonomisi için FKE'nin hesaplandığı sınırlı sayıda çalışmanın olduğu görülmüştür (Kara vd. (2012, 2015) ile Wacker vd. (2014)). Söz konusu çalışmalarda son dönemde geliştirilen dinamik faktör ve FAVAR modellerinden ziyade, VAR modelleri veya basit temel bileşenler yöntemi kullanılmıştır. Kara vd.'nin (2012) 2005:2-2012:2 dönemini kapsayan çalışmalarında, sadece yerel ve yerel faktörlere ek olarak küresel faktörlerin de dikkate alındığı iki farklı endeks hesaplanmıştır. Küresel faktörlerin finansal koşullar üzerindeki etkisinin göz önünde bulundurulması amacıyla, küresel talep ve küresel risk iştahını yansıtan iki değişken kullanılmıştır. VAR modelinin kullanıldığı çalışmada, hesaplanan endeksler örneklem içi ve örneklem dışı öngörü gücü açısından karşılaştırılmıştır. Küresel finansal koşulları kapsayan ve sadece yerel finansal değişkenlerden oluşan endekslerin, toplam üretimi açıklama güçleri sırasıyla yüzde 41 ve yüzde 48 olarak bulunmuştur. Aynı yöntemin kullanıldığı Kara vd.'nin 
(2015) çalışmasında ise, Türkiye ekonomisi için 2006:4-2014:3 dönemini kapsayan FKE hesaplanmıştır. Söz konusu endekste küresel kriz dönemlerinde dış koşulları yansıtan göstergelerin ağırlıklarının fazla olduğu, 2011 sonrasında ise diğer koşulların göreli olarak daha önemli hale geldiği tespit edilmiştir.

Euro bölgesi dışındaki önemli ekonomiler için FKE'lerin hesaplandığı çalışmada Wacker vd. (2014) ABD, Japonya ve Birleşik Krallık olmak üzere 3 sanayileşmiş ülke ile gelişmekte olan ülkelerden Çin, Brezilya, Rusya, Hindistan ve Türkiye'yi ele almışlardır. Temel bileşenler yönteminin uygulandığı çalışmada; 2000 yılından itibaren Türkiye ekonomisi için FKE hesaplanarak, elde edilen endeksler üzerinden GSYiH'daki değişimler öngörülmüştür. Örneklem dışı öngörü performansı açısından hesaplanan endekslerin, analiz kapsamındaki ülkelerin birçoğu için kısa dönemde GSYiH artışının iyi bir öngörücüsü olduğu sonucuna ulaşılmıştır.

\section{Veri Seti}

Bu çalışmada Türkiye için FKE'lerin hesaplamasında, 1992:1 ile 2015:12 dönemini kapsayan aylık veriler kullanılmıştır. Literatür taramasında da değinildiği üzere dışa açık ve küçük ekonomilere ilişkin endekslerin hesaplanmasında, yerel değişkenlerin yanı sıra küresel değişkenlerin de endeks kapsamında yer alması gerektiğine ilişkin genel bir kabul söz konusudur. Bu nedenle hesaplanacak endeksler, yerel ve küresel değişkenleri içerecek şekilde kapsamlı olarak ele alınmıştır. Hesaplanacak endekslerin mevcut çalışmalara göre önemli bir farkı, çok daha uzun bir örneklem dönemini kapsamasıdır. Böylece Türkiye ekonomisinde krizlerin yaşandığı 1994, 2001 ve 2008 yıllarında endeksin verdiği sinyallerin değerlendirilmesi amaçlanmaktadır. Hesaplanacak endeksin sürekli olarak güncellenebilmesi ve kullanılması planlanan yöntemlerin geniş örneklem hacmine ihtiyaç duyması nedeniyle aylık veriler kullanılmıştır. İktisadi aktivitenin temsilcisi olarak GSYiH yerine, sanayi üretim endeksi hedef değişken olarak tercih edilmiştir.

Endekslerin hesaplanmasında kullanılan değişkenler Tablo 1'de yer almaktadır. PKE'nin genişletilmiş versiyonu olarak da tanımlanan FKE'nin kapsamında döviz kuru ve kısa dönem faiz oranları yer almak zorundadır. Bu nedenle reel efektif döviz kuru (REER) ve TCMB gecelik borçlanma faiz oranı (INT) değişkenleri kullanılmaktadır. Berument, Ceylan ve Doğan'da (2014) olduğu üzere; bankalararası gecelik faiz oranı ile hazine bonosu faizleri arasındaki fark, prim değişkeni (SPREAD) olarak kullanılmıştır. Bankaların özel sektöre verdiği toplam krediler (CREDIT), doğrudan yabancı sermaye yatırımları (FDCl) ve M1 dar tanımlı para arzı (M) ise miktar değişkenleri olarak endeks kapsamında yer almıştır. Anket verilerine dayanan reel sektör güven endeksi (CONF), tüketici fiyat endeksi (CPI) ve Borsa İstanbul 100 endeksi (BIST) kullanılan diğer yerel değişkenlerdir. Yerel finansal koşullara ek olarak VIX oynaklık endeksi (VIX), S\&P500 hisse senedi endeksi (SP500) ve Petrol ihraç Eden Ülkeler Örgütü (OPEC) petrol varil fiyatı (OIL) değişkenleri ise küresel finans koşullarının yansıtılması amacıyla kullanılmıştır. Çalışmada kullanılan tüm seriler, Datastream veri tabanından temin edilmiştir. ${ }^{4} \mathrm{FKE}$ 'lerin hesaplanmasından önce Goodhart ve Hofmann (2001), Montagnoli ve Napolitano (2006) ile Gauthier vd.'de (2004) ol-

\footnotetext{
${ }^{4}$ Modelde kullanılan tüm değişkenlerin (faiz oranı ve prim değişkenleri hariç) doğal logaritması alınmıştır. Analiz kapsamında yer alan değişkenlerden mevsimsellik etkisi gösteren seriler, Census X-13-Tramo prosedürü aracılığıyla söz konusu etkiden arındırılmıştır. Osorio vd. (2011), Matheson (2011), Chow (2013), Thompson vd. (2013), Kara vd.'de (2012, 2015) olduğu gibi tüm seriler standardize edilmiştir. Değişkenlerin durağanlığı genişletilmiş Dickey Fuller (ADF), PhillipsPerron (PP) ve Kwiatkowski-Phillips-Schmidt-Shin (KPSS) birim kök testleri ile araştırılmıştır. Sonuçlara göre tüm seriler en az yüzde 5 anlamlılık düzeyinde durağandır.
} 
duğu gibi; Hodrick Prescot (1997) filtresi uygulanarak serilerin uzun dönem denge değerlerinden farkı alınmıştır. Sanayi üretim endeksine söz konusu dönüştürme yapılarak elde edilen seri ise üretim açığı olarak tanımlanmaktadır.

Tablo 1: Veri Seti

\begin{tabular}{|c|c|c|c|}
\hline \multicolumn{3}{|c|}{ Hedef değişken: Sanayi üretim endeksi $(2010=100)(I P)$} & \multirow{2}{*}{ Küresel Değişkenler } \\
\hline & Yerel Değişkenler & & \\
\hline $\begin{array}{l}\text { Tüketici fiyat endeksi } \\
(2010=100) \\
(\mathrm{CPI})\end{array}$ & $\begin{array}{l}\text { Borsa İstanbul } 100 \text { endeksi } \\
\qquad \begin{array}{c}(2010=100) \\
(B I S T)\end{array}\end{array}$ & $\begin{array}{l}\text { Reel sektör güven en- } \\
\text { deksi }(2010=100) \\
\text { (CONF) }\end{array}$ & $\begin{array}{l}\text { VIX oynaklık endeksi } \\
\text { (VIX) }\end{array}$ \\
\hline $\begin{array}{l}\text { Reel efektif döviz } \\
\text { kuru }(2010=100) \\
\text { (REER) }\end{array}$ & $\begin{array}{l}\text { Bankalar arası gecelik faiz oranı ve } \\
\text { hazine tahvil getiri farkı (SPREAD) }\end{array}$ & $\begin{array}{l}\text { Doğrudan yabancı ser- } \\
\text { maye yatırımları } \\
\text { (Milyon ABD Doları) } \\
\text { (FDCI) }\end{array}$ & $\begin{array}{l}\text { S\&P500 hisse senedi en- } \\
\text { deksi (SP500) }\end{array}$ \\
\hline $\begin{array}{l}\text { TCMB gecelik borç- } \\
\text { lanma faizi (INT) }\end{array}$ & $\begin{array}{c}\text { Bankaların özel sektöre verdiği top- } \\
\text { lam kredi (Milyon TL) (CREDIT) }\end{array}$ & $\begin{array}{c}\text { M1 Para arzı } \\
\text { (Milyon TL) (M) }\end{array}$ & $\begin{array}{l}\text { OPEC petrol varil fiyatı } \\
\text { (ABD Doları) (OIL) }\end{array}$ \\
\hline
\end{tabular}

\section{Metodoloji}

\subsection{Indirgenmiş Form Talep Modeli}

Türkiye için FKE'lerin hesaplanmasında dikkate alınan ilk yöntem indirgenmiş form toplam talep denklemleridir. Daha önce de belirtildiği üzere söz konusu yöntem, IS ve Phillips eğrilerinin eşanlı bir denklem sistemi içerisinde tahminlenmesi esasına dayanmaktadır. Bu çerçevede Goodhart ve Hofmann $(2000,2001,2002)$ ile Gauthier vd.'de (2004) yer alan aşağıdaki denklem sistemi tahmin edilmiştir:

$$
\begin{aligned}
& y_{t}=\alpha_{1}+\sum_{i=1}^{m} \delta_{i} y_{t-i}+\sum_{i=1}^{n} \sum_{j=1}^{n i} \lambda_{i, j} X_{i, t-j}+\varepsilon_{t} \\
& \pi_{t}=\alpha_{2}+\sum_{i=1}^{m 1} \beta_{i} \pi_{t-i}+\sum_{j=1}^{m 2} \beta_{j} y_{t-j}+\sum_{k=0}^{m 3} \beta_{k} \text { oil } l_{t-k}+\varepsilon_{t}
\end{aligned}
$$

Bu denklem sisteminde $y_{t}$ üretim açığını, $X_{i, t}$ Tablo 1'de yer alan tüketici fiyat endeksi ve petrol fiyatları dışındaki değişkenleri içeren vektörü temsil etmektedir. $\pi$ tüketici fiyat enflasyonunu, oil ise petrol fiyatlarını yansıtmaktadır. ${ }^{5}$

Endeks bileşenlerinin ağırlıkları Goodhart ve Hofmann (2001) çalışmasında olduğu gibi hesaplanmıştır. Buna göre herhangi bir açıklayıcı değişkenin endeks ağırlığı, ilgili değişkenin IS denkleminden elde edilen anlamlı katsayısının mutlak değerinin, tüm anlamlı açıklayıcı değişkenlerin katsayılarının mutlak değerlerinin toplamına bölünmesiyle elde edilmektedir.

\subsection{Genelleştirilmiş VAR Etki-Tepki Fonksiyonları}

Çalışmanın bu kısmında Goodhart ve Hofmann (2001), Gauthier vd. (2004), Swiston (2008), Osorio vd. (2011) ve Kara vd.'nin $(2012,2015)$ çalışmalarında olduğu gibi FKE, aşağıdaki VAR modeli üzerinden hesaplanmıştır:

$$
X_{t}=A_{0}+\sum_{i}^{p} A_{i} X_{t-i}+\varepsilon_{t}
$$

\footnotetext{
${ }^{5}$ Söz konusu otoregresif dağıtılmış gecikmeli modelin gecikme sayısının belirlenmesinde yine Goodhart ve Hofmann (2001, 2002) ile Gauthier vd.'de (2004) olduğu gibi genelden özele (generalized to specific) yöntemi kullanmıştır. Bu amaçla on ikinci gecikmeden itibaren geriye doğru anlamlı tüm gecikmeler muhafaza edilip, anlamsız gecikmeler dışlanmıştır.
} 
Burada $X_{t}$ Tablo 1'de yer alan tüm değişkenleri içeren içsel değişkenler vektörünü, $A$ katsayılar vektörünü ve $\varepsilon_{t}$ ise hata terimleri vektörünü göstermektedir. FKE ise aşağıdaki ağırlıklandırma yöntemi ile hesaplanmaktadır:

$$
F K E_{t}=\sum_{j=1}^{n} a_{j}\left(x_{j, t}\right)
$$

Burada $a_{j}, x_{j}$ finansal değişkenlere atanan ağırlıkları göstermektedir. Ağılıklar daha öncede belirtildiği gibi $x_{j}$ değişkenine verilen bir birimlik şoka, üretim açığının ilk 24 dönemde verdiği birikimli tepkiler kullanılarak elde edilmektedir. Daha açık bir şekilde ifade etmek gerekirse $x_{j}$ değişkenine şok verilmesi durumunda söz konusu değişkenin endeks ağırlığı; üretim açığının ilgili değişkene verdiği tepkinin mutlak değerinin, sistemdeki tüm değişkenlere şok verilmesi durumunda üretim açığının verdiği tepkilerin mutlak değerlerinin toplamına bölünmesiyle elde edilmektedir. Bu bağlamda endeks bileşenlerinin ağılıkları aşağıdaki denklem aracılığıyla hesaplanmıştır:

$$
a_{j}=\frac{\mid \text { tepki }_{j, i p} \mid}{\sum_{j=1}^{n} \mid \text { toplam tepkiler }_{i p} \mid}
$$

\subsection{Genelleştirilmiş Dinamik Faktör Modeli}

VAR modellerinden elde edilen FKE, etki-tepki fonksiyonlarının ağırlıklı ortalaması alınarak dolaylı yoldan hesaplandığından eleştirilmektedir. Bu nedenle son dönemdeki çalışmalarda, FKE'nin çok sayıda değişkenin ortak eğilimini yansıtacak şekilde elde edilmesine imkan tanıyan faktör modelleri tercih edilmeye başlanmıştır. Bu çalışmada önceki çalışmalarda kullanılan temel bileşenler yönteminden ziyade; son dönemlerde Forni, Hallin, Lippi ve Reichlin (2000a,b) tarafından geliştirilen genelleştirilmiş dinamik faktör modelleri (generalized dynamic factor model, GDFM) üzerinden FKE hesaplanmıştır. Matheson (2011) ile Osorio vd.'nin (2011) çalışmalarında kullandıkları GDFM'nin genel yapısını, Fiorentini ve Planas (2003: 12) aşağıdaki biçimde ifade etmektedir:

$$
Z_{t}=C_{q}(L) Y_{t}+\zeta_{t}=\chi_{t}^{q}+\zeta_{t}
$$

Burada $Z_{t}$ ve $Y_{t}$ sırasıyla $N \times 1$ boyutundaki değişkenler vektörünü ve $q \times 1$ boyutundaki gözlemlenemeyen ortak faktörler (unobservable common factors) vektörünü ifade etmektedir. $q$ ise $\left(y_{1 t}, \ldots, y_{q t}\right)$ dikeysel ortak faktörleri (orthogonal common factors) yansıtmaktadır. $L$ gecikme operatörünü (lag operator), $\zeta_{t}$ ise $N \times 1$ boyutundaki sıra dışı bileşenler (idiosyncratic components) vektörünü göstermektedir. $N \times 1$ boyutundaki $\chi_{t}^{q}$ vektörü, serilerin ortak bileşenleridir. Referans serisi olarak tanımlanan üretim açı̆̆ının ortak bileşeni ise FKE'dir. ${ }^{6}$ $\left(\operatorname{cov}\left(\chi_{t}^{q}, \zeta_{t}\right)=0\right)$ varsayımı nedeniyle izgisel yoğunluk matrisi (spectral density matrix), serilerin ortak ve sıra dışı bileşenlerinin yoğunluk matrisleri toplamına eşittir. Forni vd.'nin (2000b) yaklaşımlarından hareketle; izgisel yoğunluk matrisinin özdeğerlerinin en büyük değere sahip olanının $(q)$, değişkenler vektörü üzerine izdüşümüyle (projection) ortak bileşen matrisi aşağıdaki biçimde elde edilmektedir:

$$
\chi_{t}^{q^{*}}=K^{q}(L) Z_{t}
$$

Yukarıdaki denklem sisteminde $K^{q}(L)$ ve $\chi_{t}^{q^{*}}$, sırasıyla filtre ve ortak bileşen matrisleridir. $K^{q}(L)$ 'nin çokterimli (polynominal) matrisinin, frekans bölgesi $(0, \pi)$ içerisinde kullanılan sıklık

\footnotetext{
${ }^{6}$ Elde edilen endeksler üretim açığının değerlendirilmesinde kullanılacağından, referans serisi olarak sanayi üretimi seçilmiştir.
} 
sayısı $M$ olarak ifade edilmektedir. $2 M+1$ sayıda sıklık için $K^{q}(w)$ matrisi, ters Fourier dönüşümü ile aşağıdaki şekilde elde edilir: ${ }^{7}$

$$
K_{i j k}^{q}(L)=\frac{1}{2 M+1} \sum_{k=0}^{2 M+1} K_{i j}^{q}\left(w_{k}\right) e^{i k w_{k}}
$$

Yukarıda izlenen adımlar sonunda, her bir serinin ortak ve geçici bileşenleri ayrıştırılabilir (Fiorentini ve Planas, 2003: 12-14). Buradan referans serisi olarak üretim açığının kullanıldığı FKE, tüm serilerin ortak bileşeni olarak aşağıdaki denklemden elde edilmektedir:

$$
y_{t}=F K E_{t}^{q^{*}}+\zeta_{t}^{*}
$$

\subsection{FAVAR Modelleri}

FAVAR modellerinde değişkenler gözlemlenebilen ve gözlemlenemeyen olmak üzere ikiye ayrılmaktadır. FKE'lerin FAVAR modellerinden elde edilmesinde Koop ve Korobilis'den (2013, 2014) hareketle dinamik model ortalaması (DMA) kullanılmıştır. Markov zincir ve durum-uzay modellerinin eşanlı olarak tahmin edildiği DMA, değişken sayısının referans değişkene en iyi uyum sağlayacak şekilde zaman içerisinde değişmesine imkan tanımaktadır (Raftery, Karny ve Ettler, 2010: 52). Dolayısıyla DMA ile hesaplanan endekslerdeki değişkenlere ait ağırlıklar zamanla değişmektedir.

Tahmin edilen TVP-FAVAR modeli, Koop ve Korobilis'de $(2013,2014)$ olduğu gibi aşağıdaki biçimde tanımlanabilir:

$$
\begin{array}{ll}
x_{t}=\lambda_{t}^{y} y_{t}+\lambda_{t}^{f} f_{t}+u_{t} & u_{t} \sim N\left(0, V_{t}\right) \\
{\left[\begin{array}{l}
y_{t} \\
f_{t}
\end{array}\right]=c_{t}+B_{t}\left[\begin{array}{l}
y_{t-1} \\
f_{t-1}
\end{array}\right]+\varepsilon_{t}} & \varepsilon_{t} \sim N\left(0, Q_{t}\right) \\
\lambda_{t}=\lambda_{t-1}+v_{t} & v_{t} \sim N\left(0, W_{t}\right) \\
\beta_{t}=\beta_{t-1}+\eta_{t} & \eta_{t} \sim N\left(0, R_{t}\right)
\end{array}
$$

(10) nolu denklem sistemindeki $y_{t}, N \times 1$ boyutundaki üretim açı̆̆ını; $x_{t}$ ise endeks kapsamında yer alan değişkenler vektörünü ifade etmektedir. $\lambda_{t}$ ve $\beta_{t}$ ise sırasıyla $\lambda_{t}=\left(\left(\lambda_{t}^{y}\right)^{\prime},\left(\lambda_{t}^{f}\right)^{\prime}\right)^{\prime}, \beta_{t}=\left(c_{t}^{\prime}, \operatorname{vec}\left(B_{t}\right)^{\prime}\right)^{\prime}$ olarak tanımlanmaktadır. $f_{t}$ skalar olup analize dahil edilen tüm değişkenlerin ortak eğilimini yansıtan örtük faktörü (latent factor), yani hesaplanan FKE'yi yansıtmaktadır. Bu model rassal yürüyüş sürecine göre faktör yüklerinin, regresyon katsayılarının ve VAR katsayılarının zaman içerisinde değişimini sağlamaktadır (Koop ve Korobilis, 2013: 4).

(10) ve (11) nolu denklemlerdeki hata terimlerinin birbirleriyle korelasyon halinde olmadığı varsayılırsa, hata terimlerinin zamanla değişen kovaryans matrisi aşağıdaki gibi elde edilir (Koop ve Korobilis, 2013: 4):

$$
\left(\begin{array}{l}
u_{t} \\
\varepsilon_{t} \\
v_{t} \\
\eta_{t}
\end{array}\right) \sim N\left(0,\left[\begin{array}{llll}
V_{t} & 0 & 0 & 0 \\
0 & Q_{t} & 0 & 0 \\
0 & 0 & W_{t} & 0 \\
0 & 0 & 0 & R_{t}
\end{array}\right]\right)
$$

${ }^{7} w,[-\pi, \pi]$ aralığında yer alan bir sıklıktır. 
$V_{t}, Q_{t}, W_{t}$ ve $R_{t}$ hata kovaryanslarının belirlenmesinde $\kappa_{1}, \kappa_{2}, \kappa_{3}$ ve $\kappa_{4}$ azaltma faktörlerini (decay factors) içeren, üssel ağırlıklandırılmış hareketli ortalama (exponentially weighted moving average, EWMA) yöntemi kullanılmaktadır. Bu yaklaşımda başlangıçtaki gözlemler azaltılarak, son gözlemlere daha fazla ağırlık verilmektedir (Koop ve Korobilis, 2013: 5, 23). Model $V_{t}^{\prime}$ 'nin köşegen matris ve $\lambda_{t}^{f}$ 'nin ilk elemanın $1^{\prime}$ e eşit olduğu varsayımlarını içerdiğinden, TVPFAVAR modelinin tahminlenmesiyle tek bir örtük faktör (FKE) elde edilecektir.

(10) ve (11)'deki kısıtsız TVP-FAVAR modeline $\lambda_{t}=\lambda$ kısıtı konursa, sabit faktör yükleri elde edilebilmektedir; ancak modelin VAR parametreleri halen zamanla değişen yapıdadır. $\lambda_{t}$ birçok parametre içerdiği için $(n \times(s+1)=12 \times(2)=24)$, kısıtlı hale getirilmesi gereksizdeğişken (over-parameterization) sorununun azaltılması açısından önem taşımaktadır. Söz konusu kısıtlı model, genişletilmiş faktör TVP-VAR ya da FA-TVP-VAR olarak adlandırılmaktadır (Koop ve Korobilis, 2013: 6).

FA-TVP-VAR modeline getirilen ek kısıtlar $\left(W_{t}=R_{t}=0\right)$, hata terimlerinin sabit ve değişen varyansa sahip olduğu FAVAR modellerinin de elde edilmesini sağlamaktadır. Bu modellerden değişen varyanslı-FAVAR (HT-FAVAR) modelini elde etmek için FA-TVP-VAR modeline $V_{t}=V$, $\lambda_{t}=\lambda, \beta_{t}=\beta$, ve $W_{t}=R_{t}=0$ kısıtları getirilmektedir. Eş varyanslı FAVAR (HM-FAVAR) modeli için, ek olarak $Q_{t}=0$ kısıdının getirilmesi gerekmektedir. ${ }^{8}$ Bu modellerin katsayıları zamanla değişen yapıda olmasa da, elde edilen endeks ağırlıkları zamanla değişen yapıdadır (Koop ve Korobilis, 2013, 2014).

\section{Ampirik Sonuçlar}

\subsection{Indirgenmiş Form Talep Modeli}

FKE'nin indirgenmiş form talep modelinden elde edilmesi için (1) ve (2) nolu denklem eşanlı olarak tahmin edilmiştir. Denklem tahmin sonuçlarına göre VIX oynaklık endeksi hariç, katsayıların işaretleri iktisadi beklentiler ile uyumludur. VIX oynaklık endeksi küresel riski yansıtan bir değişken olduğundan, üretim açığını azaltması beklenmektedir. Geriye kalan değişkenlerin toplam talep modelinden elde edilen katsayılarının işaretleri ise beklentiler doğrultusunda bulunmuştur. ${ }^{9}$ Indirgenmiş form talep denklemi endeks ağırlıkları Tablo 2' de yer almaktadır. Bankaların özel sektöre verdiği toplam krediler ve doğrudan yabancı sermaye yatırımları hiçbir gecikmede anlamlı sonuçlar vermediği için, IS denkleminin nihai tahminlemesinde yer almamaktadır. Endeks bileşenleri arasında en büyük ağırlık reel sektör güven endeksine aittir. Ayrıca küresel faktörleri yansıtan değişkenlerden VIX oynaklık endeksi ve S\&P500 hisse senedi endeksleri, toplam endeks ağırlığının yaklaşık yüzde 30'unu oluşturmaktadır. İndirgenmiş form talep modelinden elde edilen FKE ve sanayi üretimi arasındaki ilişki Şekil 1'de sunulmuştur. Üretim açığı ile benzer bir seyir izleyen FKE, 1994 ve 2001 krizlerindeki dönüm noktalarını doğru bir şekilde tespit etmiştir. Ancak 2008 küresel finans krizinde, üretimde yaşanan düşüşe sınırlı ölçüde tepki vermiştir.

\footnotetext{
${ }^{8}$ TVP-FAVAR modeline getirilen kısıtlar $V_{t}, Q_{t}, W_{t}$ ve $R_{t}$ hata kovaryanslarının belirlenmesinde kullanılan $\kappa_{1}, \kappa_{2}, \kappa_{3}$ ve $\kappa_{4}$ azaltma faktörleri üzerinden gerçekleşmektedir. Kısıtsız TVP-FAVAR modelinde azaltma faktörleri sırasıyla $\kappa_{1}=0.96$, $\kappa_{2}=0.96, \kappa_{3}=0.99$ ve $\kappa_{4}=0.99^{\prime}$ dur. FA-TVP-VAR modelinde ise $\kappa_{1}=0.96, \kappa_{2}=0.96, \kappa_{3}=1$ ve $\kappa_{4}=0.99^{\prime}$ dur. Değişen varyanslı-FAVAR modeli $\kappa_{1}=0.96, \kappa_{2}=0.96, \kappa_{3}=1$ ve $\kappa_{4}=1$ parametreleriyle elde edilmektedir. Eş varyanslı FAVAR (HM-FAVAR) modelinde ise tüm azaltma faktörleri 1'e $\left(\kappa_{1}=\kappa_{2}=\kappa_{3}=\kappa_{4}=1\right.$ ) eşittir.

${ }^{9}$ Tablo 2'de yer alan FKE ağırıklarının hesaplandığı EKK tahmin sonuçlarının yazarlardan temin edilmesi mümkündür.
} 
Tablo 2: Indirgenmiş Form Talep Denklemi Endeks Ağırlıkları

\begin{tabular}{cccccccc}
\hline & REER & INT & BIST & SPREAD & CONF & VIX & SP500 \\
\hline $\begin{array}{c}\text { Anlamlı } \\
\text { Gecikmeler }\end{array}$ & $\mathbf{( - 1 )}$ & $\mathbf{( - 1 , - 4 )}$ & $\mathbf{( - 1 , - 7 )}$ & $\mathbf{( - 1 )}$ & $\mathbf{( - 1 )}$ & $\mathbf{( - 1 )}$ & $\mathbf{( - 1 , - 3 )}$ \\
Ağırlıklar & 0.082 & 0.123 & 0.080 & 0.125 & 0.291 & 0.158 & 0.138 \\
\hline
\end{tabular}

Şekil 1: IS Denkleminden Elde Edilen FKE ve Üretim Açığı

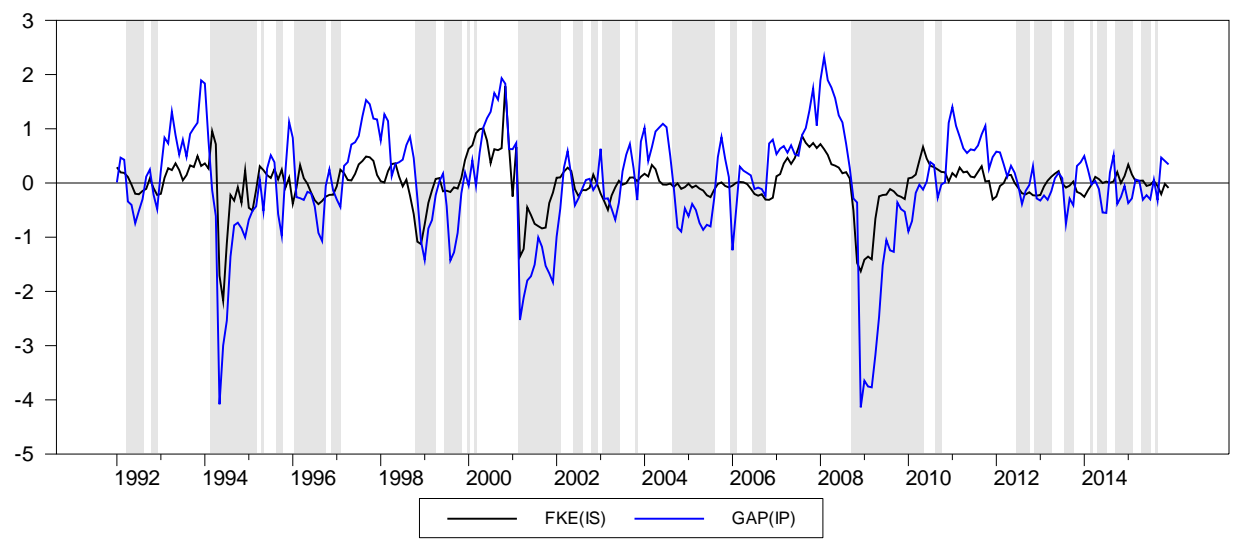

Not: Koyu renkli alanlar üretim açığının sıfırdan küçük olduğu dönemleri temsil etmektedir.

Finansal koşulların belirleyicileri açısından kredi hacmi, doğrudan yabancı sermaye yatırımları ve parasal büyüklüklerin önemli göstergeler olduğuna ilişkin literatürde genel kabul gören bir anlayış söz konusudur. Ancak indirgenmiş form talep denkleminden elde edilen FKE'nin endeks ağırlıkları açısından, söz konusu değişkenlerin herhangi bir etkisi mevcut değildir. Bu açıdan hesaplanan endeks, iktisadi aktivitedeki değişimleri yansıtmasına rağmen; endeks ağırıkları açısından politika yapıcılarına yeterli derecede bilgi sunmamaktadır. Bu noktadan hareketle Türkiye ekonomisi için alternatif FKE'lerin hesaplanmasında, daha önce yapılmış mevcut çalışmalardan farklı olarak literatürdeki tüm yaklaşımlar dikkate alınmıştır.

\subsection{Genelleştirilmiş VAR Etki-Tepki Fonksiyonları}

Genelleştirilmiş etki-tepki fonksiyonlarından elde edilen FKE'nin endeks ağırlıklarının hesaplanmasından önce, denklem 3 'de yer alan VAR modeli tahmin edilmiştir. ${ }^{10}$ Endeks bileşenlerine verilen bir birimlik şoka, üretim açığının birikimli tepkileri Şekil 2'de yer almaktadır.

Genelleştirilmiş etki-tepki fonksiyonlarında üretim açığının endeks bileşenlerine verdiği tepkilerin yönünün, iktisadi beklentiler ile uyumlu olduğu görülmektedir. Ancak doğrudan yabancı sermaye yatırımlarına (FDCl), üretim açığının verdiği tepki istatiksel olarak anlamsızdır. Bu nedenle endeksin hesaplanmasında söz konusu değişkene sıfır ağırlık verilmiştir. Üretim açığının endeks bileşenlerine verdiği yirmi dört dönem sonundaki birikimli tepkiler; (4) nolu denklemde yerine konularak endeks bileşenlerinin ağırlıkları hesaplanmış, sonuçlar Tablo 3'te sunulmuştur.

\footnotetext{
${ }^{10}$ Akaike bilgi kriterleri ile hesaplanan VAR gecikme uzunluğu iki olarak belirlenmiştir. Tahmin edilen VAR modelinin kökleri birim çemberin içerisinde yer almaktadır, dolayısıyla model istikrarlılık koşulunu sağlamaktadır. Bunun yanında artıklara uygulanan otokorelasyon, değişen varyans ve normallik sınamaları da tahmin sonuçlarının geçerli olduğunu göstermektedir.
} 
Nisan 2017, C. 12, S. 1

Şekil 2: Üretim Açığının Birikimli Tepkileri

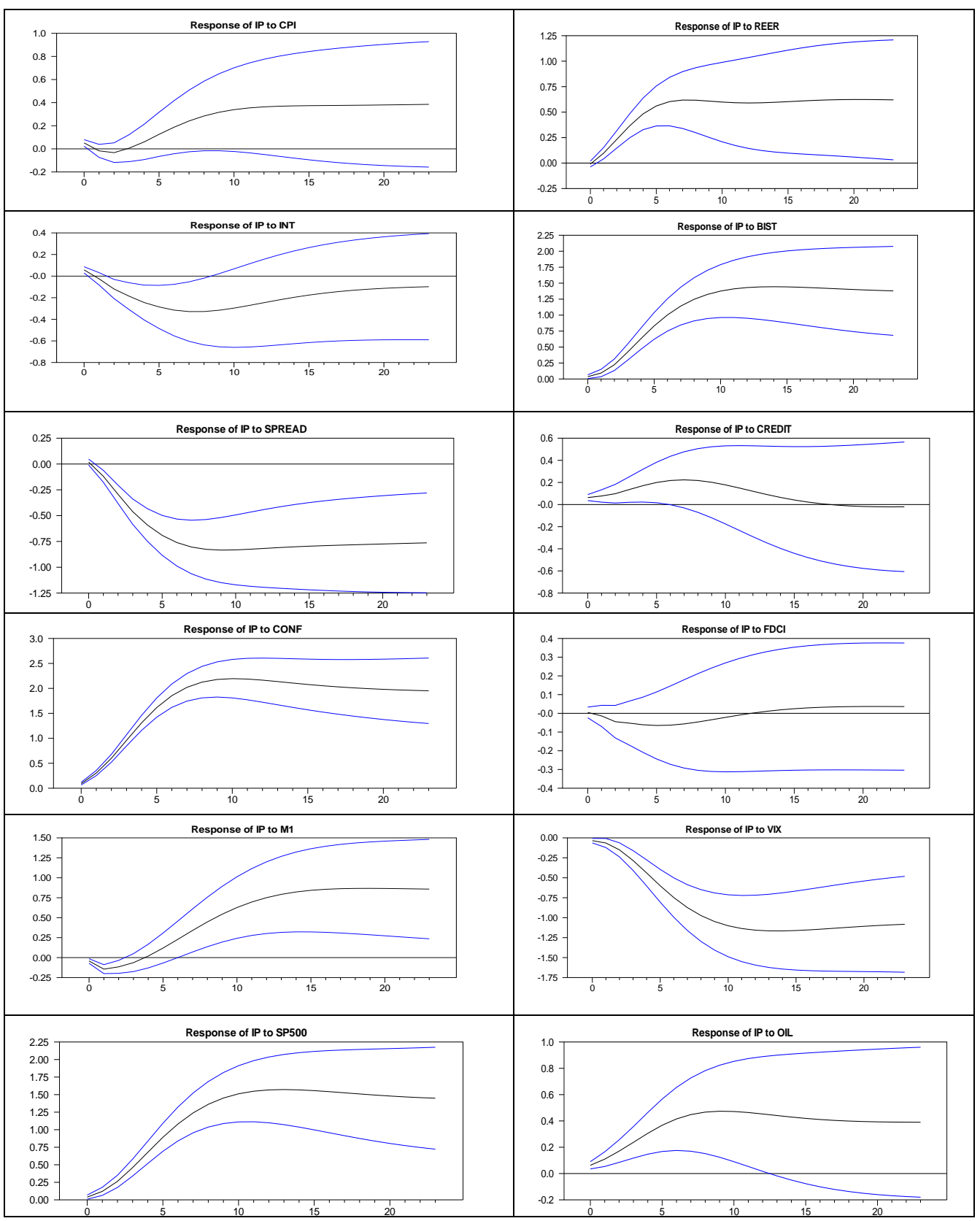


Tablo 3: VAR Modeli Etki-Tepki Fonksiyonları Endeks Ağırlıkları

\begin{tabular}{ccccccc}
\hline \multirow{3}{*}{ Ağırlıklar } & CPI & REER & INT & BIST & SPREAD & CREDIT \\
\cline { 2 - 7 } & 0.045 & 0.066 & 0.010 & 0.153 & 0.084 & 0.000 \\
\cline { 2 - 7 } & CONF & FDCI & M & VIX & SP500 & OIL \\
\cline { 2 - 7 } & 0.218 & - & 0.099 & 0.117 & 0.158 & 0.042 \\
\hline
\end{tabular}

Genelleştirilmiş etki-tepki fonksiyonlarından elde edilen endekste en büyük ağırlı̆̆ı, indirgenmiş form talep denkleminde olduğu gibi reel sektör güven endeksi almaktadır. VIX oynaklık endeksi, S\&P500 hisse senedi endeksi ve OPEC petrol fiyatlarından oluşan küresel finansal değişkenler, toplam endeks ağırlığının yaklaşık yüzde 30'unu teşkil etmektedir.

Reel efektif döviz kuru ve TCMB gecelik borçlanma faizinin toplam ağırlıkları ise yaklaşık yüzde 7 civarındadır. Bu durum PKE'nin oluşturulmasında kullanılan değişkenlerin, finansal piyasalardaki değişimlerin açıklamasında ve makro-finansal etkileşimlerin yansıtılmasında yetersiz kalabileceğini ima etmektedir. Şekil 3'te VAR modelinden hesaplanan FKE ve üretim açığı yer almaktadır. Endeks 1994, 2001 ve 2008 krizlerindeki daralmaları sınırlı bir şekilde tespit etmesine rağmen üretim açığı ile benzer seyir izlemektedir. İndirgenmiş form talep denkleminde olduğu gibi, kredi hacmi ve doğrudan yabancı sermaye yatırımlarının etki-tepki fonksiyonlarından hesaplanan FKE'de herhangi bir katkısının olmadığı görülmektedir.

Şekil 3: VAR Modelinden Elde Edilen FKE ve Üretim Açığı

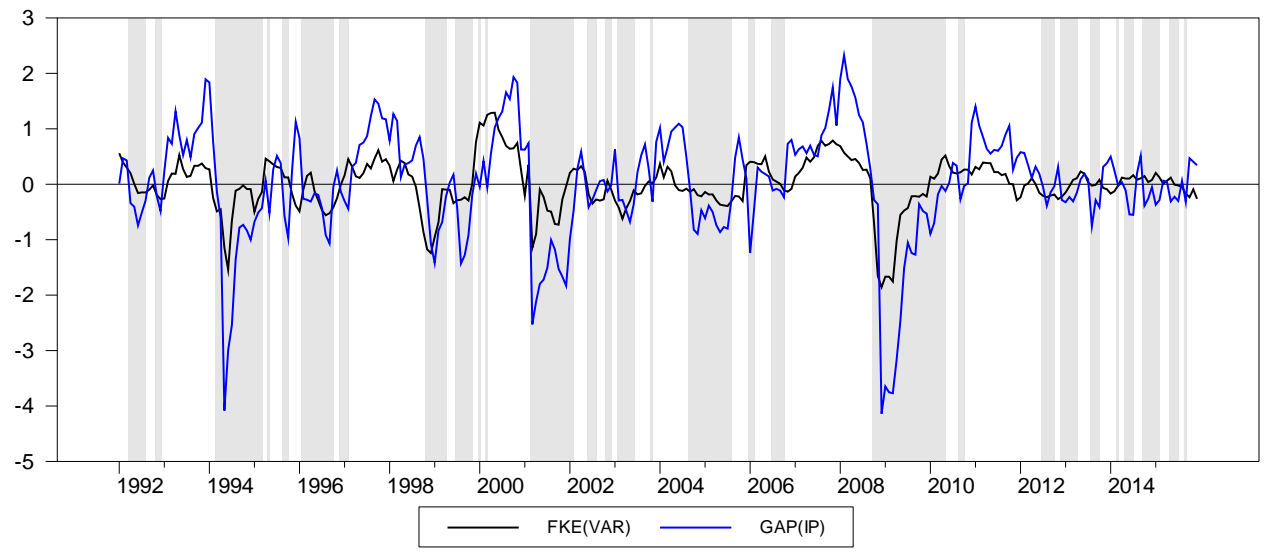

\subsection{Genelleştirilmiş Dinamik Faktör Modeli Sonuçları}

Genelleştirilmiş dinamik faktör modelinin (GDFM) tahmininden önce çeşitli parametrelerin belirlenmesi gerekmektedir. İlk olarak faktör sayısının belirlenmesinde, izgisel ayrıştırmadan elde edilen özdeğerler kullanılmaktadır. Şekil 4'te değişkenlerin ortak faktörler tarafından açıklanan varyansının grafiksel gösterimi yer almaktadır. Söz konusu grafiğe göre serilerin toplam varyansının en az yüzde 50'sinin 2 ortak faktör tarafından açıklanabilmesinden ötürü optimal faktör sayısı 2 olarak hesaplanmıştır.

Belirlenmesi gereken diğer parametre ise $M$, sıklık sayısıdır. Sıklık sayısının belirlenmesinde Forni vd.'den $(2000 a, b)$ hareket edilerek, $\sqrt{T / 4}$ formülünden yararlanılmıştır. Burada $T$ gözlem sayısıdır. Bu çalışmada 288 gözlem kullanıldığı için $M$ sayısı 4 olarak hesaplanmıştır. Şekil 5'te GDFM'den elde edilen FKE ve üretim açı̆̆ının zaman içeresindeki değişimine ilişkin grafik yer almaktadır. Şekilden de görüldüğü üzere GDFM modelinden elde edilen FKE, 
indirgenmiş form talep denklemleri ve VAR modellerine kıyasla, çıktı açı̆̆ındaki dönüm noktalarını çok daha başarılı bir şekilde tespit etmektedir. 1994, 2001 ve 2008 krizleri sonrasında üretimde meydana gelen daralmaların neredeyse tamamını yakalayabildiği görülmektedir.

Şekil 4: Ortak Faktörler Tarafından Açıklanan Varyans

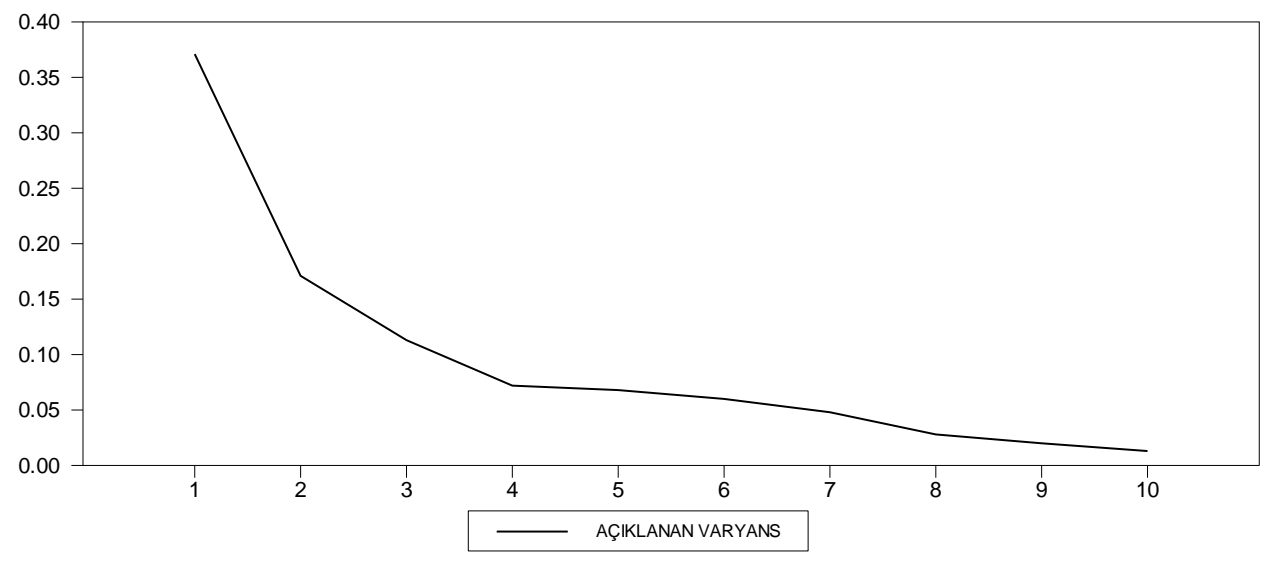

Şekil 5: GDFM'den Elde Edilen FKE ve Üretim Açı̆̆ı

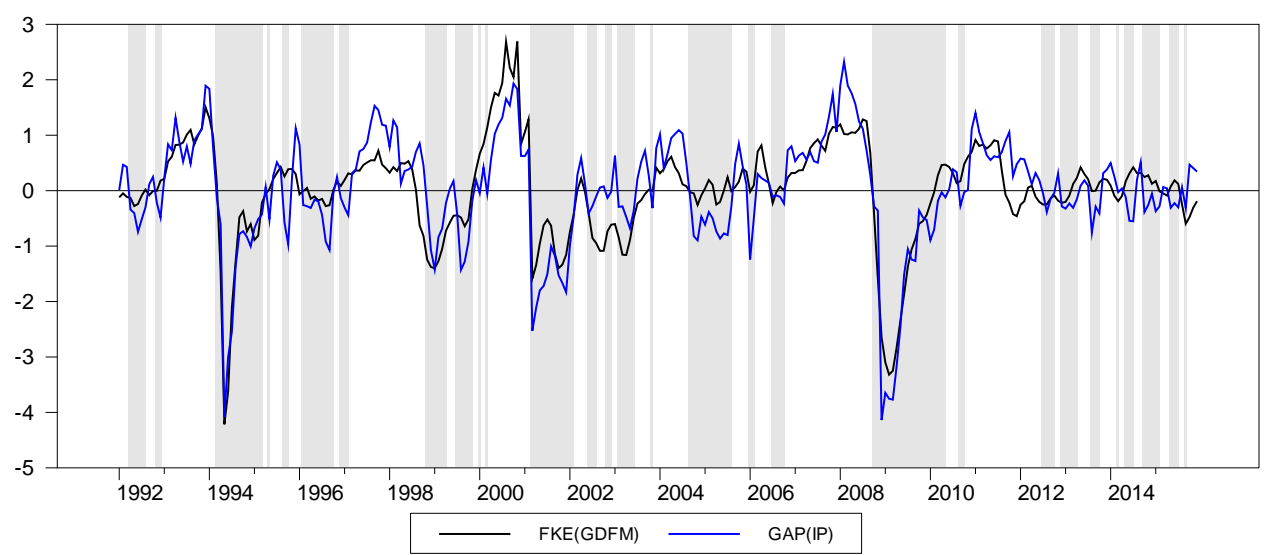

GDFM kapsamında yer alan tüm serilerin ortak bileşenlerinin referans serisiyle olan ilişkisi, ortak bileşenlerin ilk sırasındaki izgisel yoğunluk matrisinin gecikmeli ortalamasına göre hesaplanmaktadır $\sum_{\chi}^{q}\left(w_{1}\right) / w_{1}$. Buna göre ilgili değişkenin referans serisiyle en yüksek korelasyonu -1 ile +1 arasındaysa, seriler tesadüfi olarak adlandırılmaktadır (Fiorentini ve Planas, 2003: 14). Tersine eğer gecikmeli ortalama 1'den büyükse öncül, -1 'den küçükse gecikmeli seriler olarak tanımlamaktadır. Buna göre tüketici fiyat endeksi, bankaların özel sektöre verdiği krediler, doğrudan yabancı sermaye yatırımları ve prim değişkeni gecikmeli serilerdir. BIST 100 endeksi, TCMB gecelik borçlanma faizi, reel sektör güven endeksi, M1 ve VIX oynaklık endeksi öncül seriler olarak sınıflandırılmaktadır. Diğer değişkenler ise tesadüfi seriler olarak gruplandırılmaktadır. 
Forni vd.'de (2000b) olduğu gibi endeks ağırlıklarının belirlenmesinde, serilerin ortak bileşenleri ve referans serisiyle olan en yüksek korelasyonu kullanılmıştır. Bu yaklaşımdan hareketle endeks kapsamında yer alan değişkenlerin ağırlıkları Şekil $6^{\prime}$ da sunulmuştur. Endeks bileşenlerinden BIST 100 endeksi, reel sektör güven endeksi ve S\&P500 hisse senedi endekslerinin ağırlıkları diğer serilere göre daha fazladır. Ayrıca önceki yaklaşımlardan farklı olarak, GDFM ile elde edilen ağırlıklar negatif değerler alabilmektedir. Politika faiz oranı ve VIX oynaklık endeksi değişkenlerinin sanayi üretim endeksini azaltması beklenmektedir. Bu açıdan GDFM'den elde edilen ağırlıkların, iktisadi teoriyle tutarlı olduğu söylenebilir.

Şekil 6: GDFM Endeks Bileşenlerinin Ağırlıkları

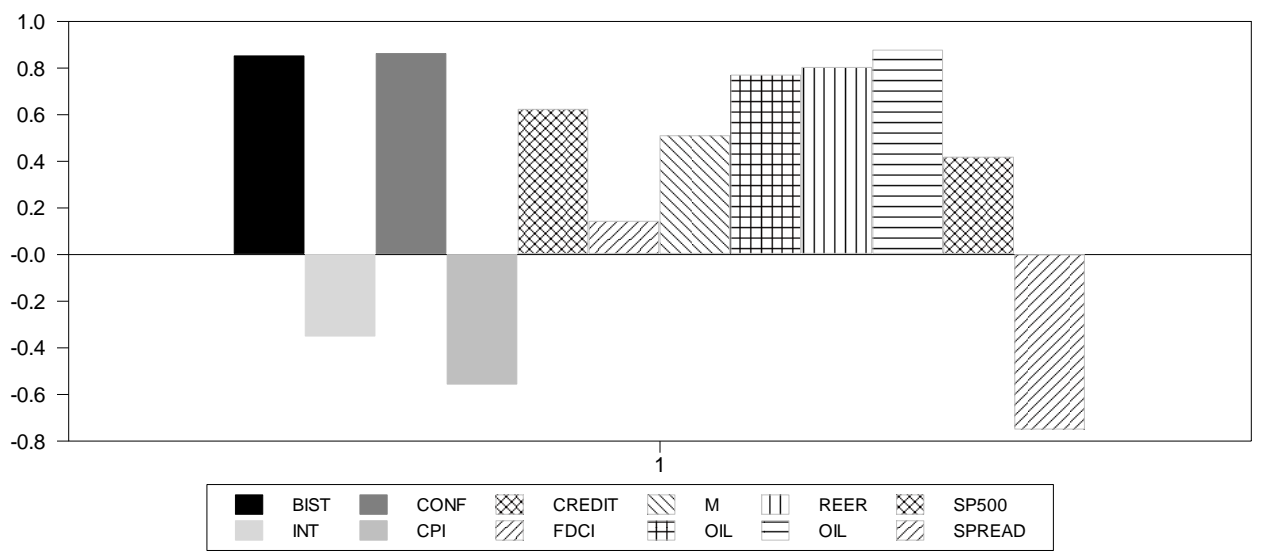

\subsection{Faktör-Genişletilmiş VAR (FAVAR) Modeli Sonuçları}

DMA'ya dayalı FAVAR modellerinin tahminlenmesiyle hesaplanan endeksler Şekil 7'de yer almaktadır. Daha öncede belirtildiği üzere, FAVAR modelleri kapsamında kısıtsız FAVAR (TVPFAVAR) ve kısıtlı FAVAR (FA-TVP-VAR, değişen varyans ve eş varyans FAVAR) üzerinden dört farklı FKE hesaplanmıştır.

Hesaplanan FKE'lerin iktisadi aktivitedeki dalgalanmaları başarılı bir şekilde tespit ettiği, özellikle kriz dönemlerinde üretimde meydana gelen düşüşleri doğru bir şekilde yansıttığı görülmektedir. Türkiye ekonomisinde yaşanan kriz dönemleri incelendiğinde, sanayi üretimindeki en büyük düşüşün 1994 ve 2008 küresel finans krizinden sonra gerçekleştiği görülmektedir. Üretim açığına paralel olarak finansal koşullarda da, söz konusu dönemlerde önemli miktarda daralma gerçekleşmiştir. FKE'lerin sanayi üretiminde meydana gelen daralmayı en iyi tespit ettiği dönemin ise 2001 krizi olduğu görülmektedir. Bu dönemde üretim açığı ile FKE’lerin aldığı değerler neredeyse birbirine eşittir. 1994, 1999, 2001 ve 2008 yıllarında meydana gelen ekonomik daralmaları doğru bir şekilde öngörebilen endeksler, 2010:09 itibariyle farklılaşmaya başlamaktadır. TVP-FAVAR, FA-TVP-VAR ve değişen varyans FAVAR (HT-FAVAR) modelleri 2010:09 sonrası gerçekleşen üretim artışını yakalayamamakta ve ters yönde sinyaller vermektedir. Ancak eş varyanslı FAVAR (HM-FAVAR) modeliyle hesaplanan endeks, 2010 sonrası üretimdeki değişimleri daha doğru bir şekilde yansıtmaktadır. Endekslerin içerdiği sinyaller ve yorumlanması, ağırlıklı toplam ve temel bileşenler analizlerinde olduğu gibidir. Yani endeksin yukarı yönlü bir hareketi finansal koşullardaki gevşemeyi gösterirken, aşağı yönlü değişimi ise finansal koşullar- 
daki daralmayı yansıtmaktadır. Kısacası kısıtlı ve kısıtsız FAVAR modelleri içerisinde ekonomideki dönüm noktalarını tespit yeteneği açısından, HM-FAVAR daha başarılı bir performans sergilemektedir.

Şekil 7: FAVAR Modelleriyle Elde Edilen FKE'ler ve Üretim Açığı

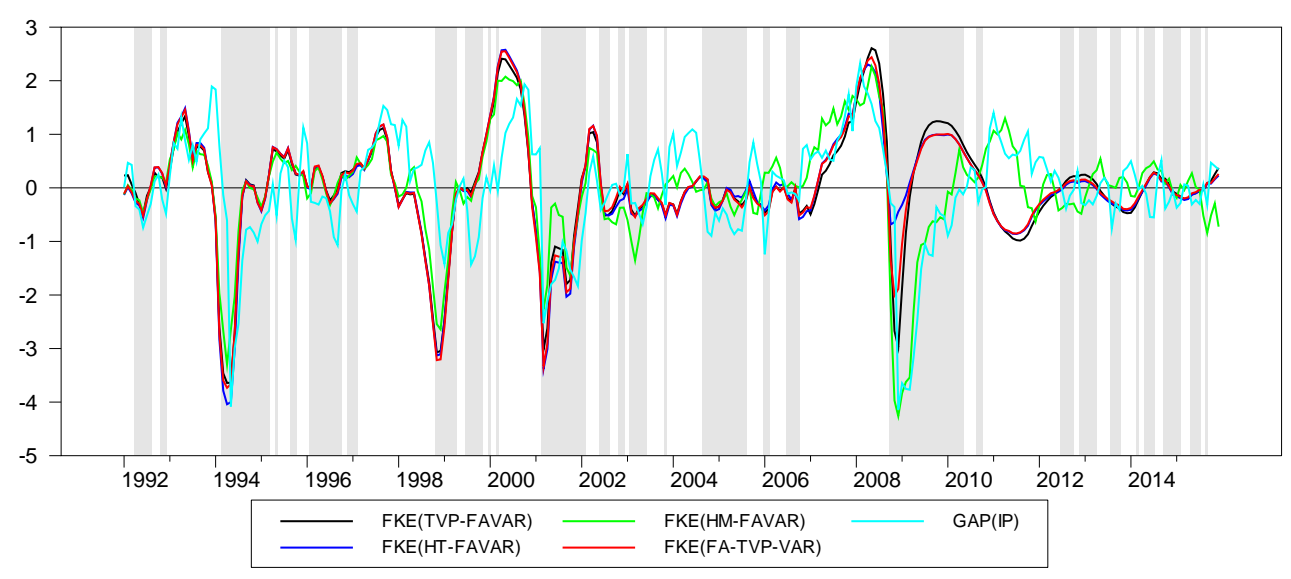

FAVAR modelleriyle hesaplanan endeks bileşenlerinin DMA ağırlıkları Şekil 8'de yer almaktadır. 0 ve 1 arasında değer alan ağılıklar, DMA prosedürünün ilgili değişkenlerin endeks kapsamında yer alma olasılıklarını ifade etmektedir. Bu açıdan TVP-FAVAR, FA-TVP-VAR ve HTFAVAR modellerinin endeks bileşenlerinin DMA ağırlıkları benzer bir seyir izlemektedir. Yerel endeks değişkenlerinden tüketici fiyat endeksi ve bankaların özel sektöre verdiği toplam kredilerin, 2008 küresel finans krizi sonrasında tüm FAVAR modellerinde oldukça arttığı görülmektedir. Ancak HM-FAVAR modeli haricinde reel efektif döviz kuru, TCMB gecelik borçlanma faizi ve BIST 100 endeksinin (başlangıç dönemi haricinde) dikkate değer bir DMA ağırlığı yoktur. HMFAVAR modelinde ise söz konusu değişkenlerin ağırlıkları 2001 ekonomik krizi sonrasında artmaktadır. FAVAR modellerinin genelinde doğrudan yabancı sermaye yatırımlarının ağırlığı, 2008 yılının ikinci yarısından itibaren ciddi bir düşüş sergilemiştir. Ancak HM-FAVAR modelinde ilgili dönemde daha kısıtlı bir düşüş yaşanmıştır. Para arzının DMA ağırlıkları, 1994 ekonomik krizine kadar Tüm FAVAR modellerinde azalma eğilimi sergilemektedir. 2003 sonrasında ise HM-FAVAR modeli haricinde, para arzı değişkeninin DMA ağırlığı sıfır olmaktadır. Prim değişkeninin (bankalar arası gecelik faiz oranı ve hazine tahvil getiri farkı) ağılığı, başlangıçta ve 2008 küresel finans krizi döneminde tüm FAVAR modellerinde azalmaktadır. Küresel endeks bileşenlerinden VIX oynaklık endeksinin, tahminlenen modellerin hiçbirinde önemli bir DMA ağırlığı yoktur. S\&P500 hisse senedi endeksinin ağırlığı, 2001 yılı başlarında tüm FAVAR modellerinde maksimum seviyesine ulaşmıştır. HM-FAVAR modeli haricinde, 2003 yılından itibaren ilgili değişkenin ağırlığı sıfıra düşmüştür. Tüm modellerde petrol fiyatlarının ağırlığı, 2008 yılında önemli bir düşüş sergilemiştir. 
Şekil 8: FAVAR Modellerinin Endeks Bileşenleri

TVP-FAVAR
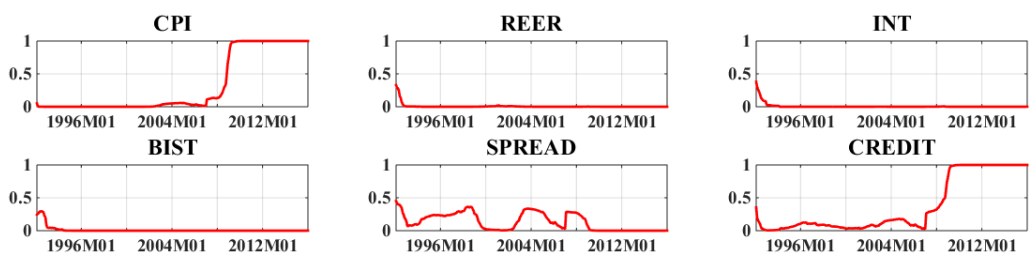
SPREAD

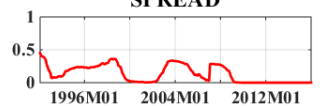
CREDIT
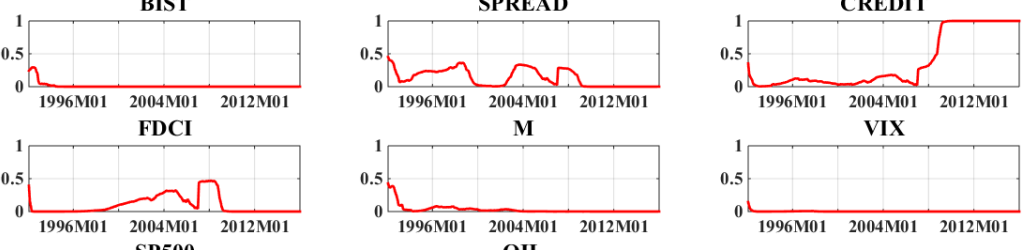
M

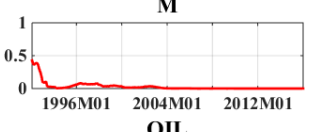
VIX
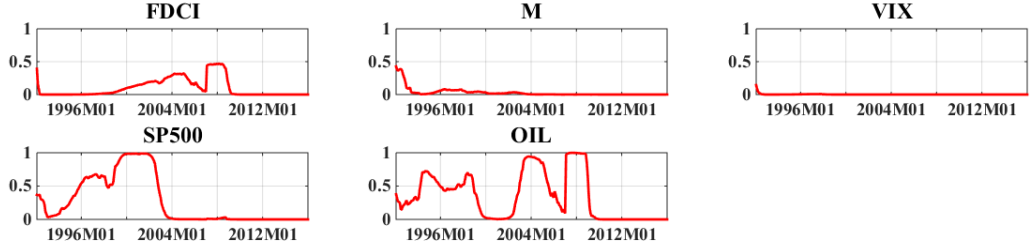

\section{FA-TVP-VAR}
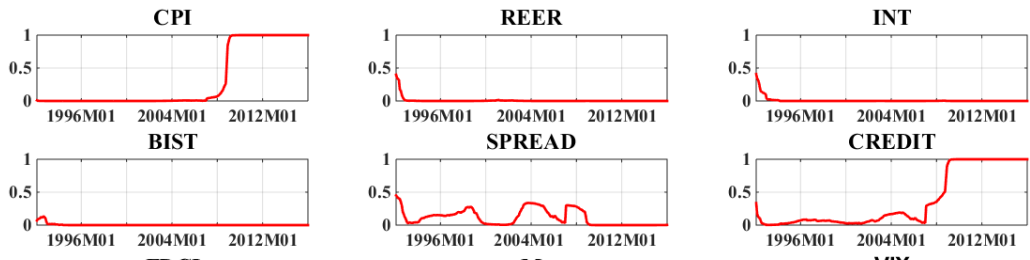

FDCI

M
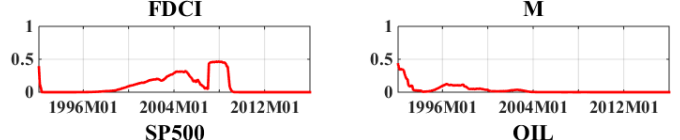

VIX
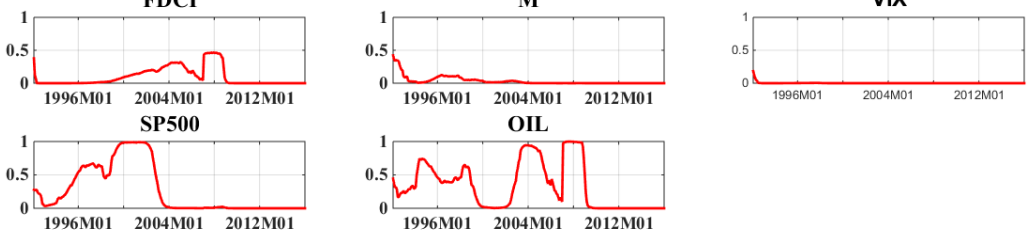

HT-FAVAR 

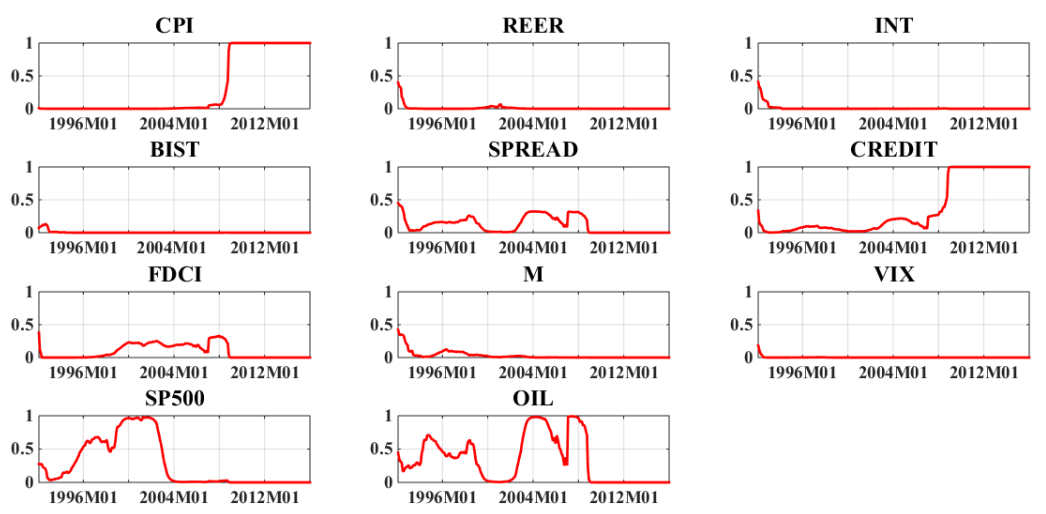

HM-FAVAR
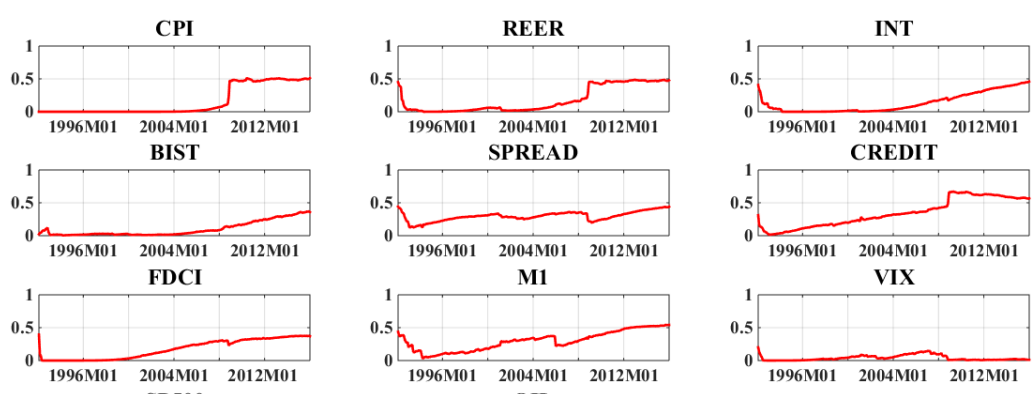
SP500
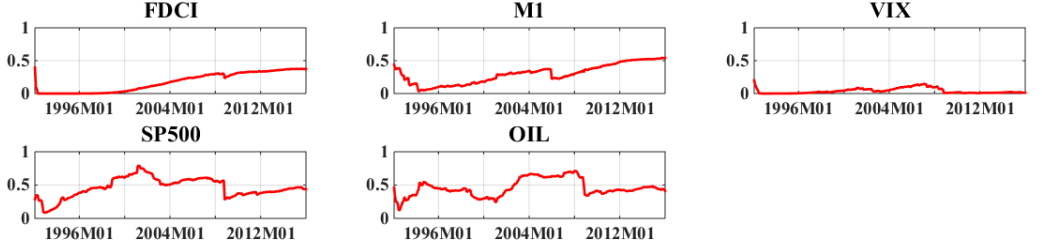

\section{FKE'lerin Öngörü Gücü Açısından Karşılaştırılması}

Çalışmanın bu kısmında çeşitli yöntemler dikkate alınarak hesaplanan FKE'ler, literatürde olduğu gibi çıktı açığını öngörebilme kabiliyetleri açısından karşılaştııılmıştır. Bu çerçevede endekslerin örneklem içi öngörü performansının belirlenmesinde, Kara vd.'den $(2012,2015)$ hareketle aşağıdaki regresyon denklemi 1992:01-2013:12 dönemi için tahmin edilmiştir. Geriye kalan 24 gözlem ise örneklem dışı öngörü performansının karşılaştırılması amacıyla kullanılmıştır.

$$
\operatorname{gap}_{t+h}=\alpha+\sum_{i=1}^{12} \operatorname{gap}_{t-i}+\sum_{i=1}^{12} F K E_{t-i}+\varepsilon_{t}
$$

Yukarıdaki modelde $F K E$ alternatif finansal koşullar endekslerini, gap ise üretim açığını ifade etmektedir. Hesaplanan endeksler yukarıdaki denklem üzerinden, üretim açığını 24 aylık öngörü gücü açısından değerlendirilmiştir. Bu amaçla (13) nolu denklemde öngörülen ( gap $\left._{t+h}\right)$ ve gerçekleşen $\left(g_{a p_{t+i}}\right)$ değerler arasındaki farkı minimize eden endeks, öngörü gücü açısından en iyi endeks olarak seçilmiştir. Söz konusu fark ortalama hata karenin karekökü (root mean square error, RMSE), ortalama mutlak hata (mean absolute error, MAE) ve Theil eşitsizlik istatistikleri üzerinden değerlendirilecektir: 


$$
\begin{aligned}
& R M S E=\sqrt{\sum_{t=T+1}^{T+h} \frac{\left(F K E_{t+h}-g a p_{t}\right)^{2}}{h}} \\
& M A E=\sum_{t=T+1}^{T+h} \frac{\left|F K E_{t+h}-g a p_{t}\right|}{h}
\end{aligned}
$$

Tablo 4'te öngörü sonuçları yer almaktadır. Örneklem içi öngörü sonuçları dikkate alındığında, GDFM'den elde edilen FKE'nin en iyi performansa sahip olduğu gözlemlenmiştir. Örneklem dışı öngörü gücü açısından ise elde edilen sonuçlar, HM-FAVAR modelinden elde edilen FKE'nin çıktı açığının iyi bir öngörücüsü olduğunu göstermektedir. Örneklem dışı öngörü sonuçlarına göre, HM-FAVAR modelinden elde edilen endeks 4 dönemde de en düşük RMSE kriterine sahiptir. MAE seçim kriteri açısından HM-FAVAR modeliyle hesaplanan endeksin, 5 dönem için minimum değerler almaktadır. Dolayısıyla hesaplanan endeksler arasında en iyi örneklem dışı öngörü performansını, HM-FAVAR modelinden elde edilen endeks göstermektedir. Bu nedenle söz konusu endeks, iktisadi aktivitenin en iyi öncül göstergesi olarak belirlenmiştir. ${ }^{11}$

Tablo 4: Endekslerin Örneklem İ̧̧i ve Dışı Öngörü Performansları

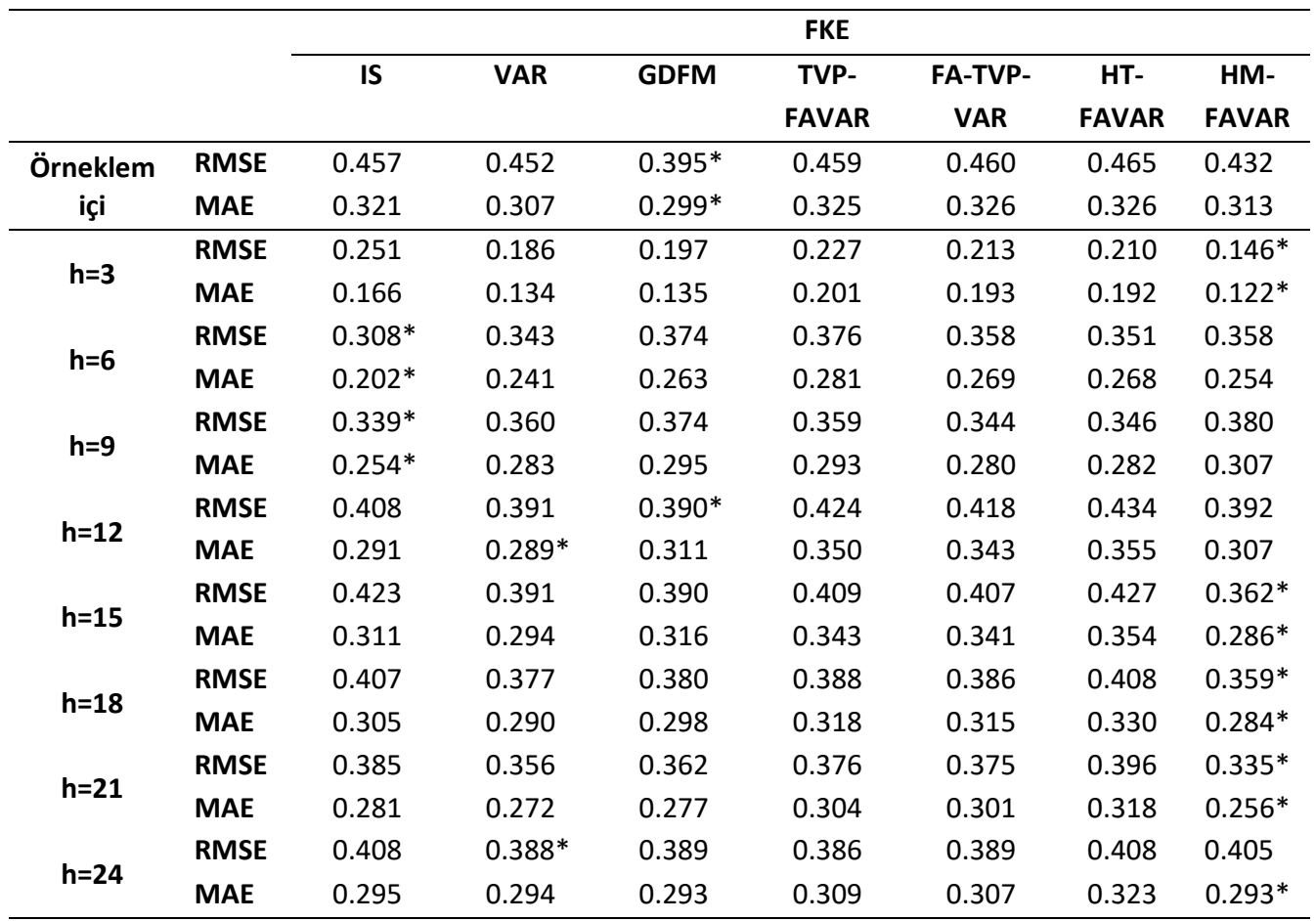

Not: Seçim kriterlerinin minimum değerleri * ile gösterilmiştir.

\section{Sonuç}

Bu çalışmada finansal piyasalardaki durumun sağlıklı bir şekilde belirlenmesi ve iktisadi aktivite üzerindeki etkilerinin değerlendirilmesi amacıyla, son dönemde geliştirilen teknikler de dikkate alınarak Türkiye için alternatif finansal koşullar endeksleri hesaplanmıştır. FKE'lerin he-

\footnotetext{
${ }^{11}$ RMSE ve MAE'nin yanında Theil istatistikleri de öngörü performansının karşılaştırılması amacı ile hesaplanmış benzer sonuçlar elde edilmiştir.
} 
saplanmasında önceki çalışmaların aksine sadece doğrusal VAR modeli dikkate alınmamış; indirgenmiş form talep denklemleri, dinamik faktör modelleri ve faktör sayısının zamanla değişmesine izin veren FAVAR modelleri de kullanılarak finansal koşullar endeksleri hesaplanmıştır.

Endeks kapsamında yer alan değişkenlerin ağırlıkları incelendiğinde, ağırlıklı toplam yaklaşımından elde edilen endekslerde reel sektör güven endeksinin ağırlığının oldukça yüksek olduğu göze çarpmaktadır. Benzer bir şekilde küresel finansal koşulları yansıtan değişkenlerin, indirgenmiş form ve VAR modelinde toplam endeks ağırlıklarının yaklaşık yüzde 30'unu oluşturduğu dikkat çekmektedir. Her iki endeks için diğer bir önemli nokta ise faiz oranı ve döviz kuru değişkenlerinin toplam ağırlıklarının yüzde 20’yi geçmemesidir. Diğer bir değişle PKE'yi oluşturan değişkenlerin, finansal koşulların çok kısıtlı bir kısmını açıklayabildiği görülmektedir. Bu çerçevede çalışmanın sonuçları Kara vd.'nin $(2012,2015)$ doğrusal VAR modellerinden elde ettikleri bulgular ile örtüşmektedir. Ağırlıklı toplam yaklaşımı için diğer bir önemli husus ise, doğrudan yabancı sermaye yatırımlarının ve kredi hacminin finansal koşullar üzerinde anlamlı bir etkisinin olmamasıdır. İktisadi aktivite ile en yüksek korelasyona sahip olan genelleştirilmiş dinamik faktör modelinden elde edilen endeksin ağılıkları, diğerlerinden farklı olarak negatif değerler alabilmektedir. Böylece endeks kapsamındaki değişkenlerin finansal koşulları ne derece açıkladığını ortaya konmasının yanı sıra, iktisadi aktivite ile endeks bileşenleri arasındaki ilişkinin yönü de incelenmektedir. Endeks ağırlıkları negatif değerler alan merkez bankası gecelik borçlanma faizi ve tüketici fiyat endeksinin, finansal koşullarla negatif yönde ilişkili olduğu tespit edilmiştir. Daha açık bir ifadeyle söz konusu değişkenlerdeki artış, FKE'yi azaltarak finansal koşulların daralmasına sebep olmaktadır. Tüketici fiyatlarındaki artışın FKE üzerindeki etkisi, merkez bankası gecelik borçlanma faizine oranla daha yüksek bulunmuştur. Endeks ağırlığı negatif değer alan son değişken ise oynaklık endeksidir. Küresel piyasalardaki artan riski ifade eden oynaklık endeksinin, merkez bankası gecelik borçlanma faizi ve tüketici fiyat endeksine göre FKE üzerine daha etkili olduğu sonucuna ulaşılmıştır.

Yukarıda ifade edilen yöntemlerden elde edilen endekslerin değişken ağırlıkları sabittir. DMA üzerinden elde edilen FAVAR modellerinin endeks ağırlıkları ise zamanla değişen yapıdadır. Bu sayede zamanla değişen bileşime sahip bir endeksin hesaplanmasının; farklı ekonomik koşullarda hangi değişkendeki değişmenin, hangi dönemde daha önemli bir rol oynadığının tespit edilmesi açısından politika yapıcılarına önemli bilgiler vereceği düşünülmektedir. Hesaplanan endeksler arasından iktisadi aktiviteyi öngörü gücü en yüksek olan endeks eş varyanslı FAVAR modelinden elde edilmiştir. Söz konusu FKE'nin ağırlıkları dikkate alındığında; 2001 krizi sonrasında reel efektif döviz kuru, merkez bankası gecelik borçlanma faizi ve BIST 100 endekslerinin finansal koşulların belirlenmesinde öneminin arttığı görülmektedir. Doğrudan yabancı sermaye yatırımları değişkeninin ağırlığı ise FAVAR modellerinin genelinde 2008 krizi sonrasında düşmüştür. Bu durum 2008 krizi sonrasında Türkiye gibi dışa açık ülkelere hız kazanan sermaye girişinin, esasında yatırım amaçlı olmadığını ima etmektedir. Eş varyanslı FAVAR modelinden elde edilen diğer bir önemli sonuç ise petrol fiyatlarının finansal koşullardaki ağırlığının, 2008 yılından itibaren önemli ölçüde düşmesidir.

Genel olarak elde edilen sonuçlar küresel koşulların Türkiye'nin finansal koşulları üzerinde önemli ölçüde etkisinin olduğunu ve PKE'nin hesaplanmasında kullanılan faiz oranı ve döviz kuru değişkenlerinin, finansal koşulların açıklanmasında yetersiz kalabileceğini göstermektedir. Dolayısıyla bu çalışmada eş varyanslı FAVAR modeli üzerinden hesaplanan FKE'nin, iktisadi aktivitenin öncül bir göstergesi olarak politika yapıcıları tarafından kullanılması önerilmektedir. Bu çalışmada FKE'nin hesaplanmasında Türkiye üzerine yapılmış önceki çalışmalara nazaran daha 
Eskişehir Osmangazi Üniversitesi iiBF Dergisi

fazla değişken kullanılmasına rağmen, gelişmiş ülkeler için yapılan çalışmalar ile karşılaştırıldığında sınırlı sayıda değişkenden yararlanılmıştır. Bu nedenle söz konusu çalışmanın ileride daha geniş bir veri seti üzerinden, gelişmiş ve gelişmekte olan ülke örneklerini içerecek şekilde ele alınması daha faydalı olacaktır. 


\section{Kaynaklar}

ANGELOPOULOU, E., BALFOUSSiA, H. ve GiBSON, H. D. (2014). "Building a Financial Conditions Index for the Euro Area and Selected Euro Area Countries: What Does it Tell Us About the Crisis?", Economic Modelling, 38, 392-403.

BAŞÇI, E. ve KARA, H. (2011). “Finansal İstikrar ve Para Politikası”, İktisat İşletme ve Finans, 26(302), 9-25.

BERUMENT, M. H., CEYLAN, N. B. ve DOĞAN, B. (2014). “An Interest-Rate-Spread-Based Measure of Turkish Monetary Policy", Applied Economics, 46(15): 1804-1813.

CHOW, H. K. (2013). "Can a Financial Conditions Index Guide Monetary Policy? The Case of Singapore", Research Collection School of Economics.

DOZ, C., GIANNONE, D. ve REICHLIN, L. (2011). “A Two-Step Estimator For Large Approximate Dynamic Factor Models Based On Kalman Filtering”, Journal of Econometrics, 164(1), 188-205.

FIORENTINI, G. ve PLANAS, C. (2003). "Busy Program User-Manual”, Joint Research Centre of European Commission, Tools and Practies for Business Cycle Analysis in European Union, EC Fifth Framework Program, Ispra, Italy.

FORNI, M., HALLIN, M., LIPPI, M. ve REICHLIN, L. (2000a). "Reference Cycles: The NBER Methodology Revisited", CEPR Discussion Papers, No: 2400.

FORNI, M., HALLIN, M., LIPPI, M. Ve REICHLIN, L. (2000b). “The Generalised Dynamic Factor Model: Identification and Estimation", Review of Economics and Statistics, 82(4), 540-554

GAUTHIER, C., GRAHAM, C. ve LIU, Y. (2004). "Financial Conditions Indexes for Canada”, Bank of Canada Working Paper, No: 2004-22.

GOODHART, C. ve HOFMANN, B. (2000). "Financial Variables and the Conduct of Monetary Policy", Sveriges Riksbank Working Paper, No: 112.

GOODHART, C. ve HOFMANN, B. (2001). "Asset Prices, Financial Conditions and the Transmission of Monetary Policy". Paper prepared for the conference on Asset Prices, Exchange Rates, and Monetary Policy, Stanford University. 2001 March.

GOODHART, C. ve HOFMANN, B. (2002). "Asset Prices and the Conduct of Monetary Policy", Royal Economic Society Annual Conference, No: 88.

GUMATA, N., KLEIN N. ve NDOU E. (2012). “A Financial Condition Index for South Africa”, IMF Working Papers, No: 196.

HATZIUS, J., HOOPER, P., MiSHKIN, F. S., SCHOENHOLTZ, K. L. ve WATSON,M. W. (2010) “Financial Conditions Indexes: A Fresh Look After the Financial Crisis", NBER Working Paper, No: 16150.

HODRICK, R. J. ve PRESCOTT, E. C. (1997). "Postwar U. S. Business Cycles: An Empirical Investigation”, Journal of Money, Credit and Banking, 29(1), 1-16.

KARA, A. H. (2012). "Küresel Kriz Sonrası Para Politikası”, TCMB Çalışma Tebliği, No: 12/17.

KARA, H., ÖZLÜ P. ve ÜNALMIŞ, D. (2012). "Financial Conditions Indices for the Turkish Economy”, CBT Research Notes in Economics, No: 2012-31.

KARA, H., ÖZLÜ, P. ve ÜNALMIŞ. D. (2015). "Türkiye için Finansal Koşullar Endeksi”, TCMB Çalışma Tebliği, No: 15/13.

KOOP, G. ve KOROBiLis, D. (2013). “A New Index of Financial Conditions”, MPRA Paper, 45463.

KOOP G. ve KOROBiLiS, D. (2014). “A New Index of Financial Conditions”, European Economic Review, 71, 101-116.

MATHESON, T. (2011). "Financial Conditions Indexes for the United States and Euro Area”, IMF Working Paper, No: $11 / 93$

MAYES, D. ve ViRÉN, M. (2001). "Financial Conditions Indexes," Bank of Finland Discussion Paper, No: 17.

MONTAGNOLI, A. ve NAPOLITANO, O. (2006). "Financial Condition Index and Interest Rate Settings: A Comparative Analysis", Department of Economic Studies, University of Naples “Parthenope”, Discussion Paper, No: 2.

OSORIO, C., PONGSAPARN, R. ve Ünsal, D. F. (2011). "A Quantitative Assessment of Financial Conditions in Asia”, IMF Working Paper Asia and Pacific Department, No: 11/173.

PARIES, M. D., MAURIN L. ve MOCCERO, D. (2014). "Financial Conditions Index and Credit Supply Shocks for the Euro Area", European Central Bank Working Paper Series, No: 1644.

PESARAN, H. H. ve SHIN Y. (1998), “Generalized Impulse Response Analysis in Linear Multivariate Models”, Economics Letters, 58(1), 17-29.

RAFTERY, E. A., KÁRNÝ, M. ve ETTLER P. (2010). “Online Prediction Under Model Uncertainty Via Dynamic Model Averaging: Application to a Cold Rolling Mill”, Technometrics, 52 (1), 52-66. 
Eskişehir Osmangazi Üniversitesi iiBF Dergisi

SWISTON, A. (2008). "A U.S. Financial Conditions Index: Putting Credit Where Credit is Due”, IMF Working Paper Western Hemisphere Department, No: 08/161.

THOMPSON, K., EYDEN R. V. ve GUPTA, R. (2013). “Identifying a Financial Conditions Index for South Africa”, University of Pretoria, Department of Economics Working Papers, No: 201333.

US BUREAU OF THE CENSUS (2013), "X-13ARIMA-SEATS Reference Manual, Version 1.1", US Bureau of the Census, Washington.

WACKER, K., LODGE, D. ve NiCOLETT, G. (2014). “Measuring Financial Conditions in Major Non-Euro Area Economies”, European Central Bank Working Papers Series, No: 1743. 